Supplementary Information for Characterization of an antibody recognizing the conserved inner core of Pseudomonas aeruginosa LPS

Elli, Stefano; Alekseeva, Anna; Ramakrishnan, Boopathy; Koch, Tyree; Andrew

Wollacott, Viswanathan, Karthik; Li, Kai; Delaney, James C.; Shriver, Zachary*; Plante,

Obadiahand Guerrini, Marco* 
$>$ VSX VH

EVKLVESGGGLVQPGGSLRLSCAASE FTFS DYAMSWVRQA PGKRLEWVAY IS SDGDSTYY PDSVKGRFT ISRDNAKN

SLYLQMNSLRAEDTAMYFCAREIRLRGYFDVWGQGTTVTVSS

$>$ VSX VL

DIQMTQSPSTLSASVGDRVTITCRASESVFGHG IS PLHWYQQKPGKAPKLLI YRASNLKSGVPSRF SGSGSRTEFTL TISSLQPDDFATYYCQQSNEY PRTFGGGTKVEIK

CDR and FW Description

\begin{tabular}{|c|c|c|c|c|}
\hline Region & Definition & Sequence Fragment & Residues & Length \\
\hline \multirow{2}{*}{ HFR1 } & Chothia & EVKLVESGGGLVQP GGS LRLSCAAS --- -- & $1-25$ & 25 \\
\hline & Kabat & EVKLVESGGGLVQP GGS LRLSCAASEFT FS & $1-30$ & 30 \\
\hline \multirow[t]{2}{*}{$\mathrm{CDR}-\mathrm{H} 1$} & Chothia & EFTFSDY--- & $26-32$ & 7 \\
\hline & Kabat & ---- DYAMS & $31-35$ & 5 \\
\hline \multirow[t]{2}{*}{ HER2 } & Chothia & AMSWVRQAPGKRLEWVAYI & $33-51$ & 19 \\
\hline & Kabat & ---WVRQAP GKRLEWVA-- & $36-49$ & 14 \\
\hline \multirow[t]{2}{*}{$\mathrm{CDR}-\mathrm{H} 2$} & Chothia & ----- SSDGDS--------- & $52-57$ & 6 \\
\hline & Kabat & ---Y ISSDGDSTYYY PDSVKG & $50-66$ & 17 \\
\hline \multirow[t]{2}{*}{ HER3 } & Chothia & TYYP DSVKGRFT IS RDNAKNSL YLQMNS LRAED TAMYF CAR & $58-98$ & 41 \\
\hline & Kabat & ------- RFT ISRDNAKN SL YLQMNS LRAED TAMYF CAR & $67-98$ & 32 \\
\hline \multirow[t]{2}{*}{$\mathrm{CDR}-\mathrm{H} 3$} & Chothia & -- EIRLRGYFDV & $99-108$ & 10 \\
\hline & Kabat & --EIRLRGY FDV & $99-108$ & 10 \\
\hline \multirow[t]{2}{*}{ HFR4 } & Chothia & -WGQGTTVTVSS & $109-119$ & 11 \\
\hline & Kabat & -WGQGTTVTVSS & $109-119$ & 11 \\
\hline
\end{tabular}

Figure S1. Sequence analysis of VSX antibody 


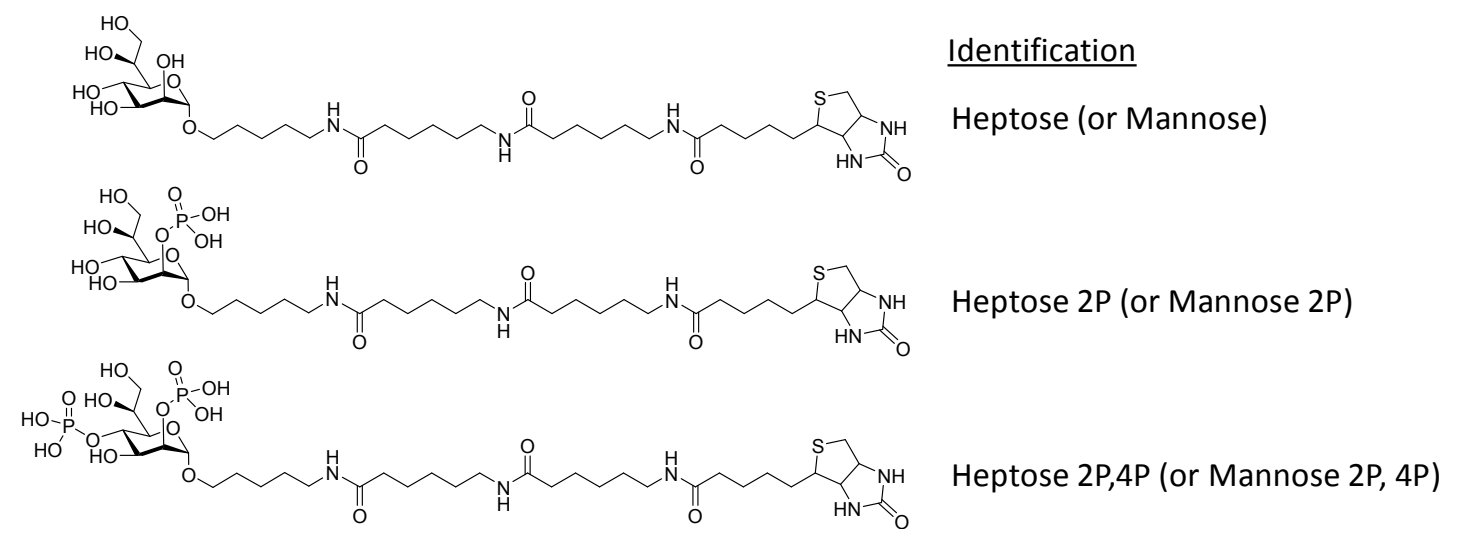

Figure S2. Structures of biotinylated saccharides used in Octet Experiments 


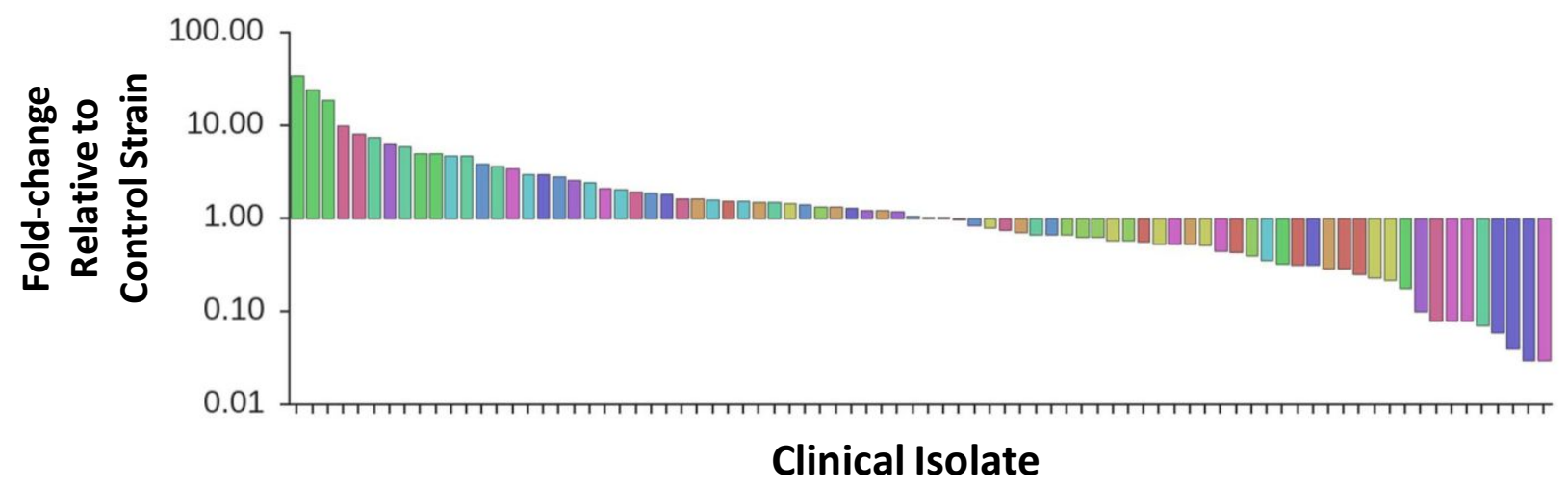

Figure S3. Whole cell ELISA evaluation of clinical isolates. VSX binds to $>100$ individual clinical isolates. Binding is depicted relative to Pae ATCC 27853. 

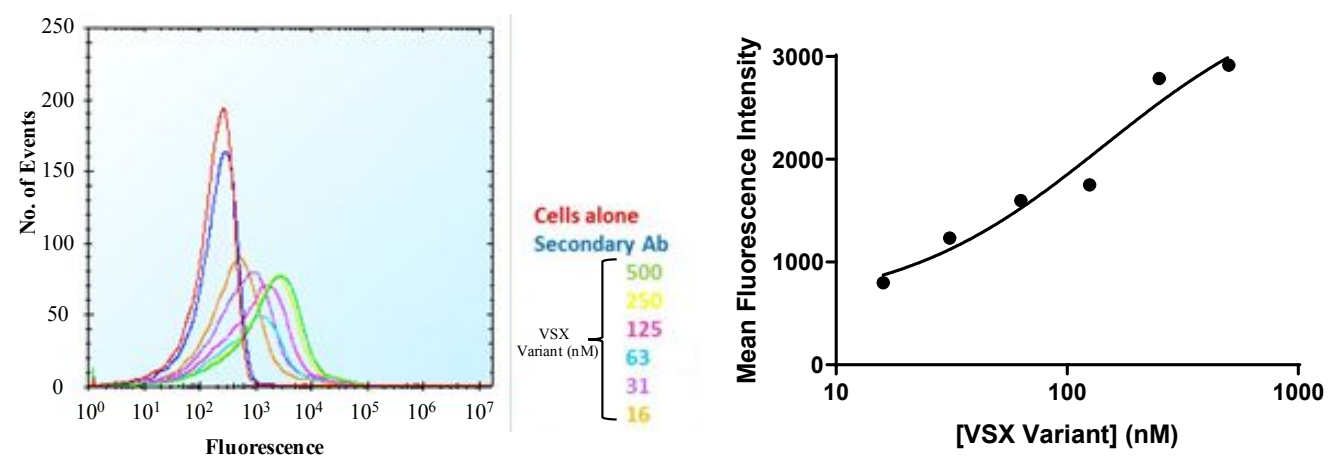

Figure S4. Flow cytometric measurement of antibody binding to Pseudomonas. Binding of a variant of VSX, at concentrations from 16-500nM, to Pae ATCC 27853. Events data (left panel) and plots of mean fluorescence intensity $v s$. antibody concentration (right panel). VSX was diluted to $2 \mathrm{x}$ test concentrations in PBS $+1 \%$ BSA and $50 \mu 1$ of each concentration was added to aliquoted cell cultures of $P$. aeruginosa strain 2785. Detection was via Goat anti-Human IgG Alexa Fluor 647 (Life Technologies) and read on an Accuri C6 with Hypercyt Intellicyt. 

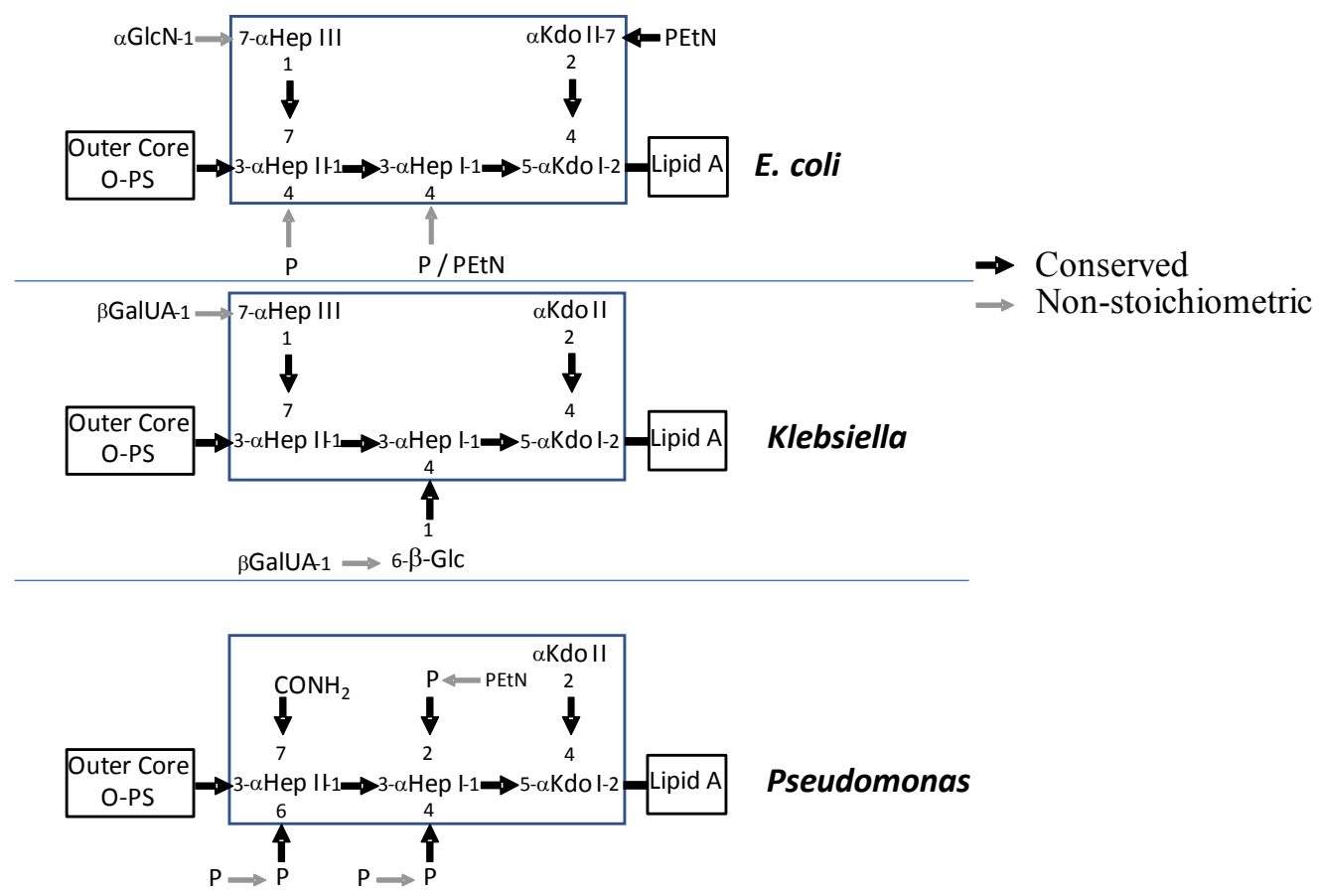

Figure S5. General structure of LPS for E coli, Klebsiella, and Pseudomonas. The blue box identifies the inner core of Pseudomonas LPS - the likely binding site for VSX. 
A

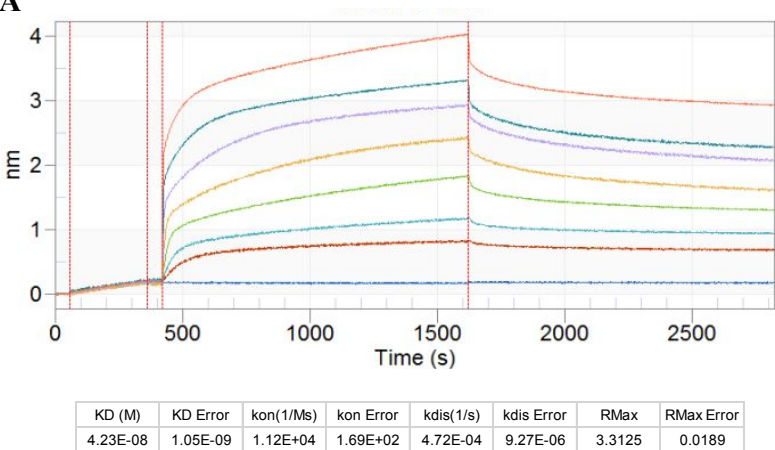

B

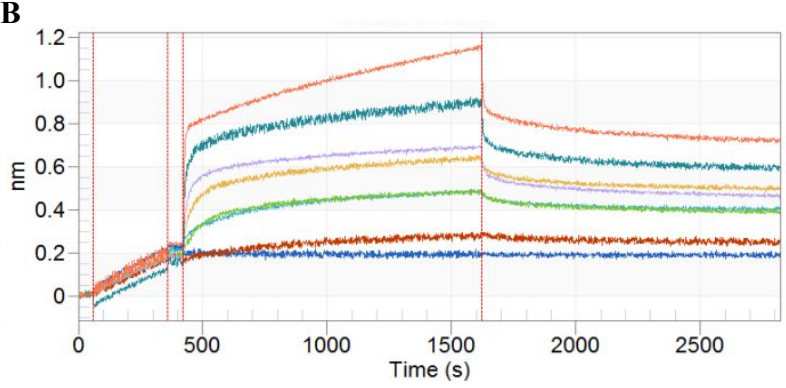

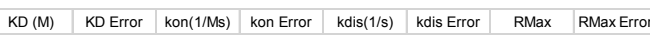
\begin{tabular}{|c|c|c|c|c|c|c|c|}
\hline $6.29 \mathrm{E}-08$ & $2.05 \mathrm{E}-09$ & $9.34 \mathrm{E}+03$ & $2.06 \mathrm{E}+02$ & $5.87 \mathrm{E}-04$ & $1.40 \mathrm{E}-05$ & 0.638 & 0.0054 \\
\hline
\end{tabular}

Figure S6. Bio-layer interferometry titration of Hep-2P,4P with (A) VSXIgG or (B) VSX Fab. The response profile was reference subtracted. Then, 1:1 global fits (linked by $\mathrm{R}_{\max }$ ) were used to calculate a $\mathrm{K}_{\mathrm{D}}$. For VSX, the calculated value is $42 \pm 1 \mathrm{nM}$; for the Fab, the calculated value is $63 \mathrm{nM} \pm 2 \mathrm{nM}$. 


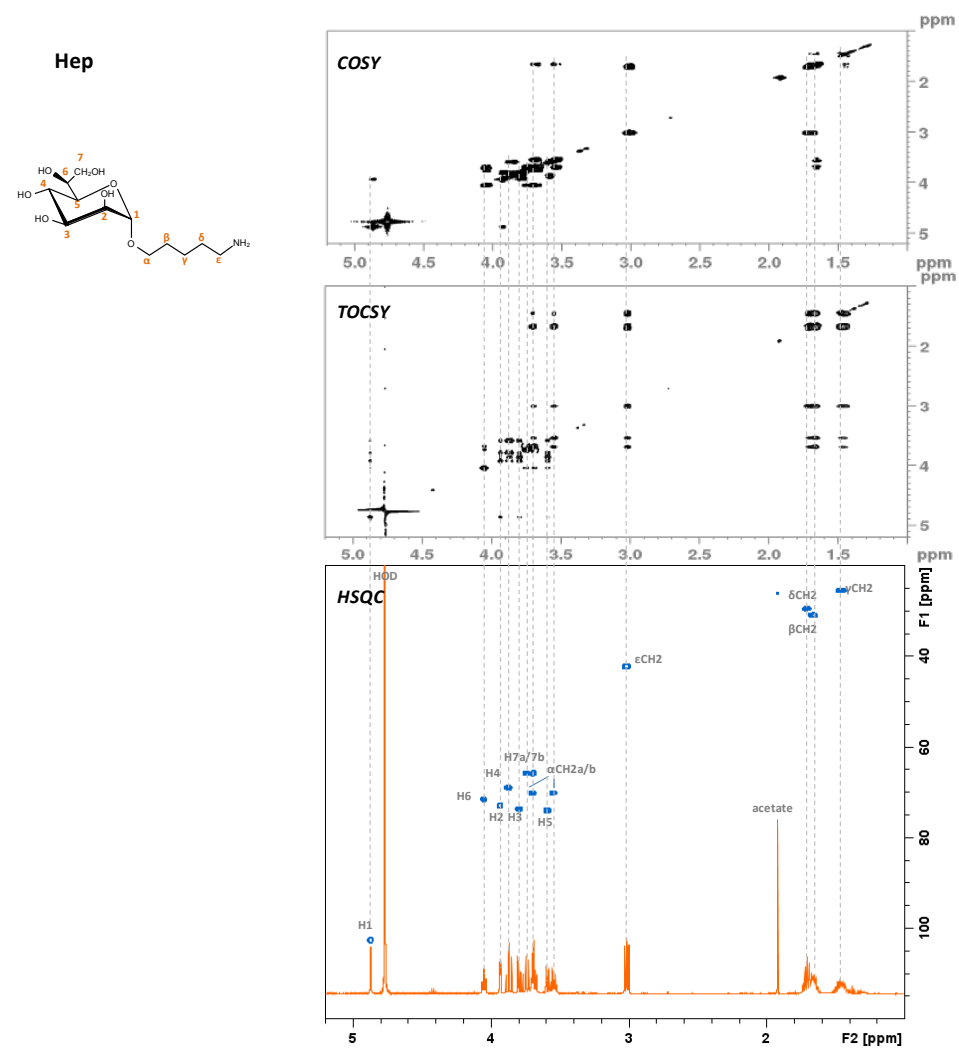

Figure S7. COSY (top panel), TOCSY (middle panel), proton and HSQC NMR spectra (bottom panel) of the non-phosphorylated heptose (Hep). 


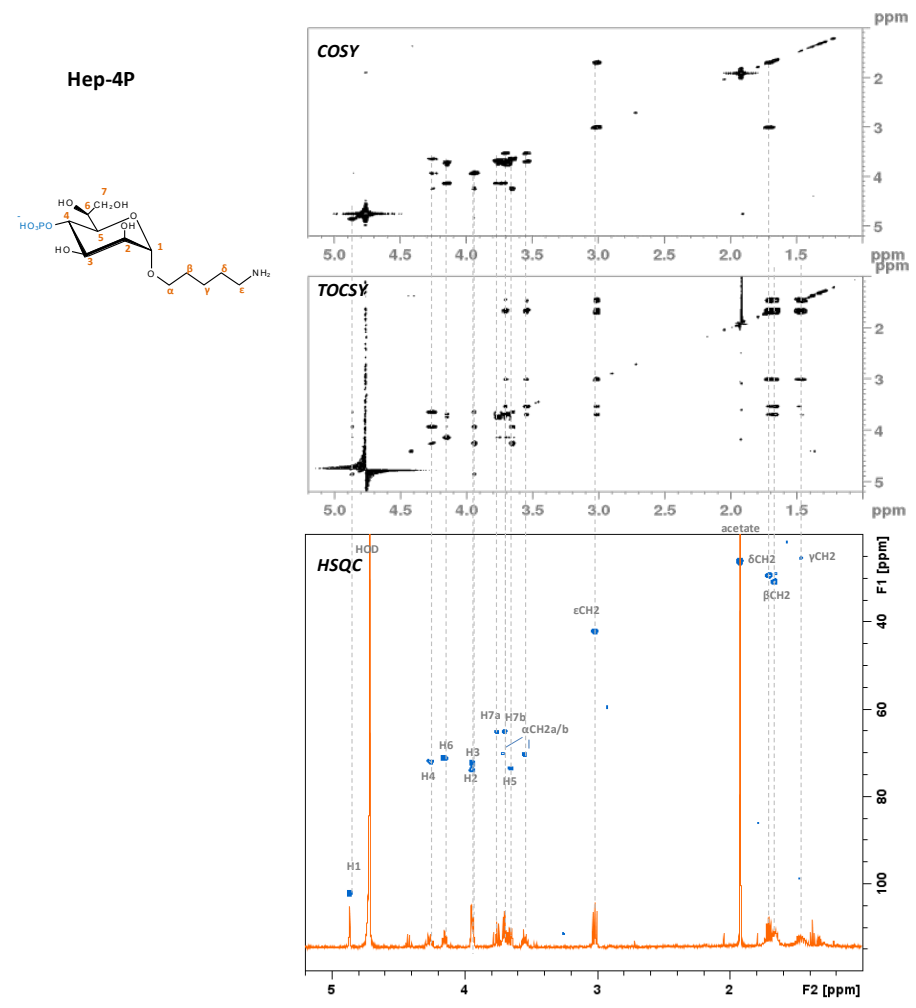

Figure S8. COSY (top panel), TOCSY (middle panel), proton and HSQC NMR spectra (bottom panel) of the heptose 4-phosphate (Hep-4P). 


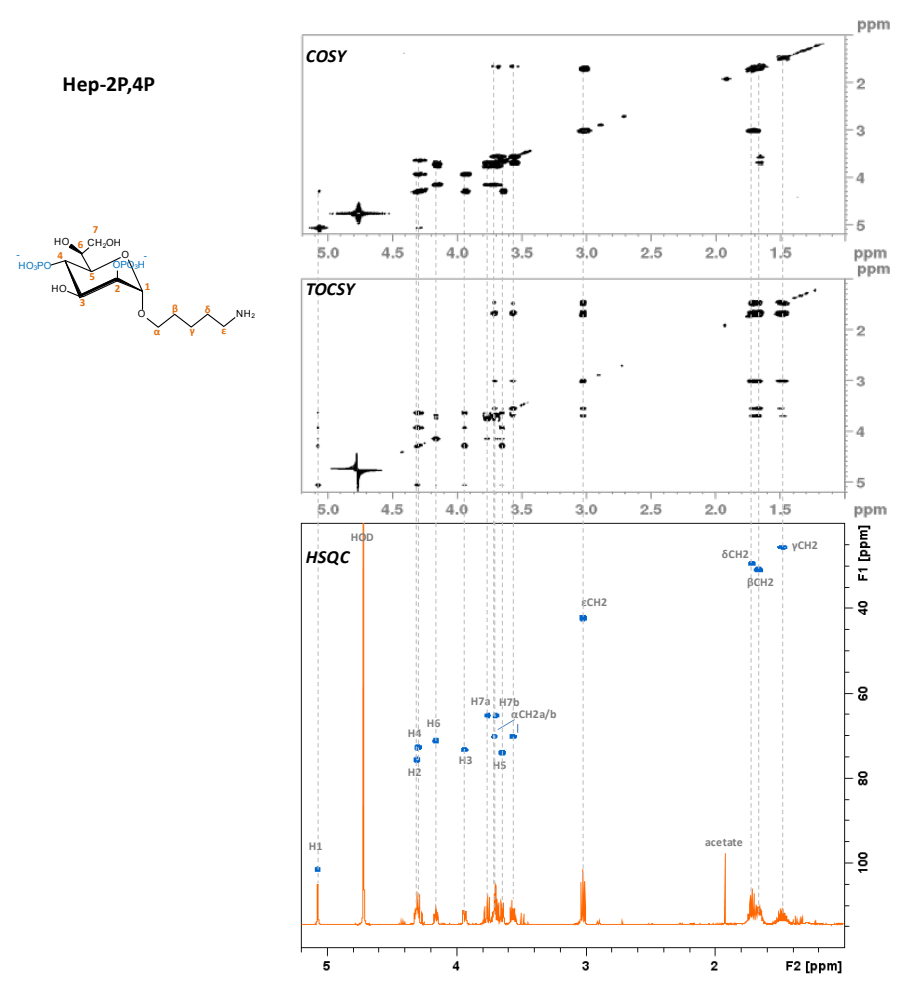

Figure S9. COSY (top panel), TOCSY (middle panel), proton and HSQC NMR spectra (bottom panel) of the heptose 2,4-bisphosphate (Hep-2P,4P). 


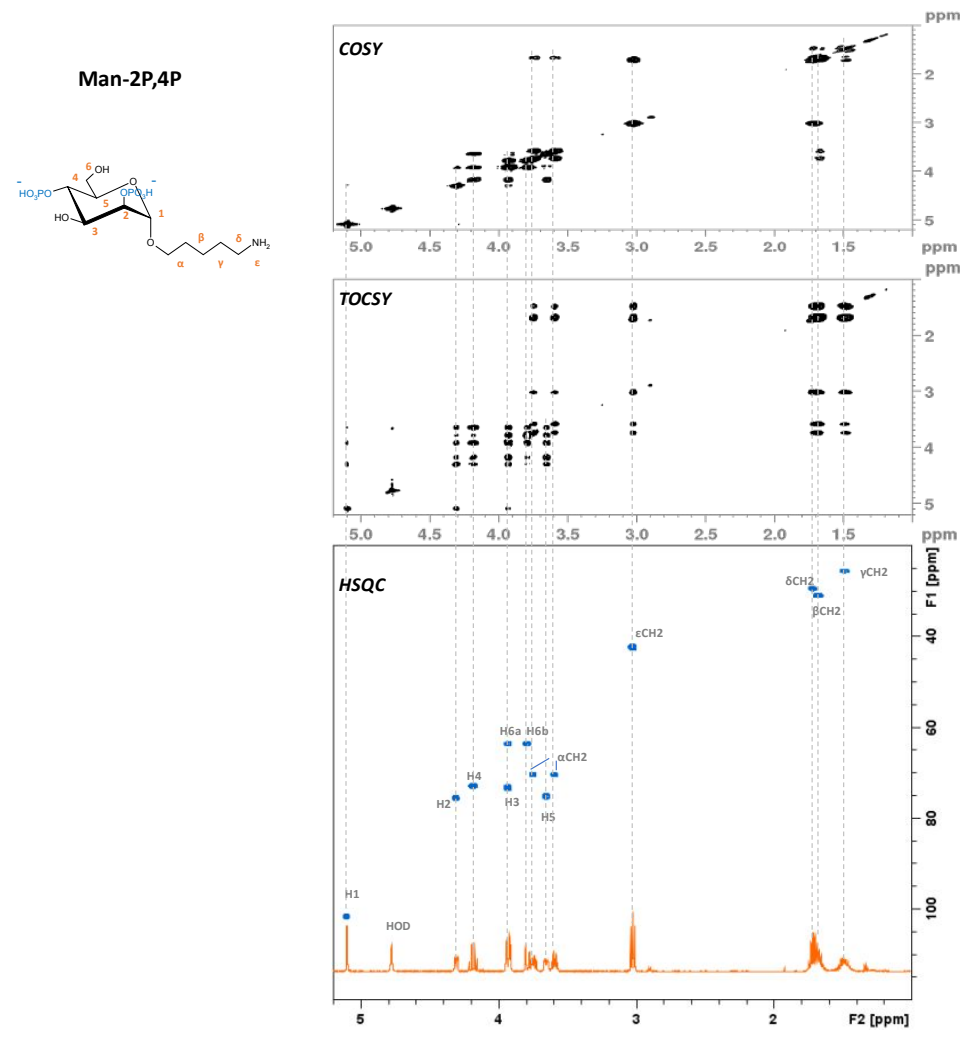

Figure S10. COSY (top panel), TOCSY (middle panel), proton and HSQC NMR spectra (bottom panel) of the 2,4-O-di-phosphorylated mannose (Man-2P,4P). 


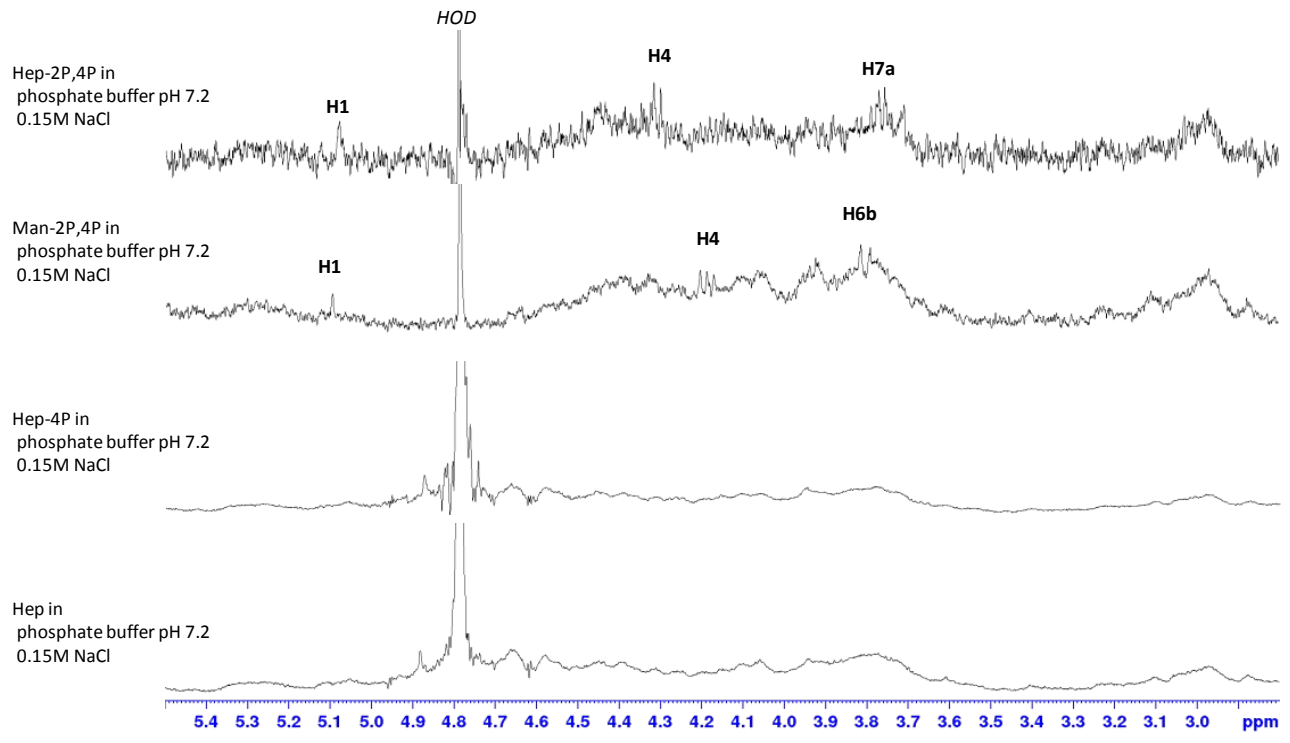

Figure S11. IH STD NMR spectra of heptose 2,4-bisphosphate, mannose 2,4-bisphosphate, heptose 4-phosphate and heptose, allowing to identify the contact atoms in the di-phosphorylated ligands. 


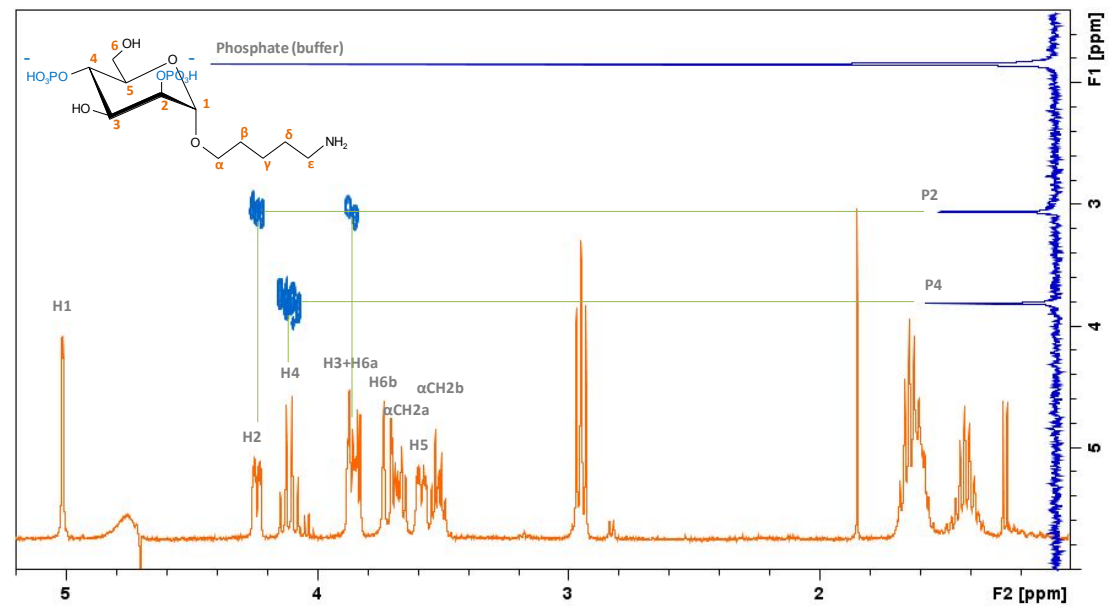

Figure S12. ${ }^{1} H_{-}{ }^{31} P$ HMBC NMR spectrum of the heptose 2,4-bisphosphate derivative. As a baseline for studies reported in Figure 3b, the HMBC spectrum for the heptose 2,4-bisphosphate. Long range correlations between proton and phosphorous signals are shown. 

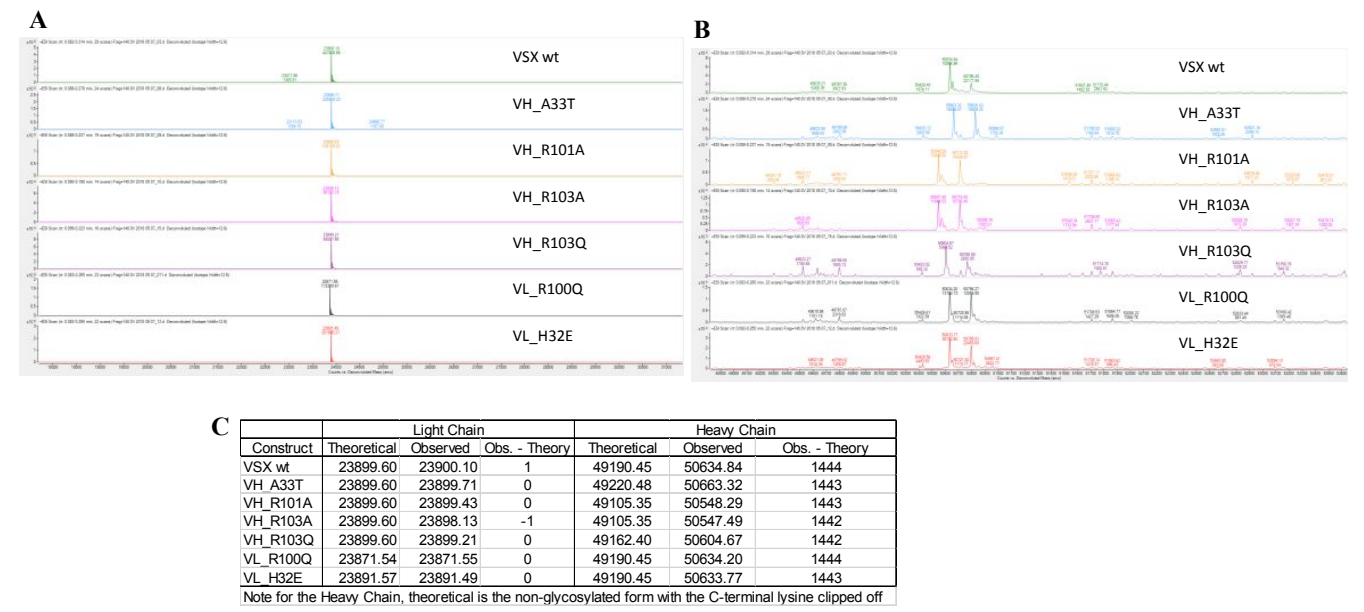

Figure S13. Assessment of VSX mutants by Q-TOF electrospray ionization mass spectrometry. Analysis of the (A) light chain and (B) heavy chain and (C) comparison of observed molecular mass to theoretical indicated that the mutants incorporated the amino acid change and were the predominant species within each antibody preparation. All antibodies were desalted, reduced, and injected directly into an Agilent 6530 Q-tof mass spectrometer. 

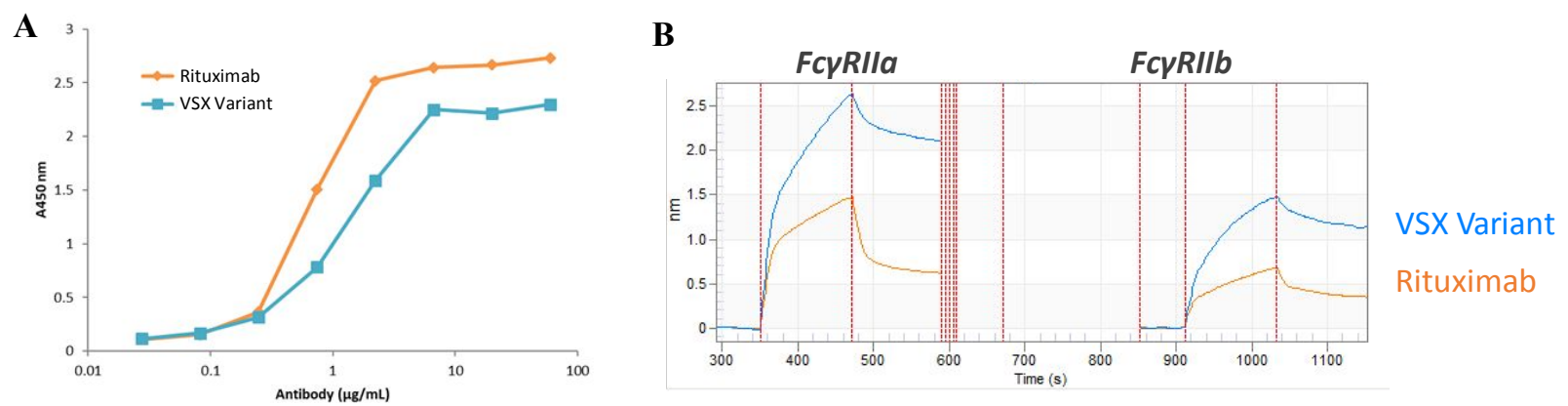

Figure S14. Binding of VSX to (A) Clq and (B) $F c \gamma R I I a / b$. A variant of VSX was assessed for its ability to engage C1q via ELISA and to Fc $\gamma$ RII via biolayer interferometry using the anti-CD20 antibody rituximab as a comparator. 


\begin{tabular}{|c|c|c|c|c|c|c|c|c|}
\hline & & $\begin{array}{l}\text { BAA- } \\
2108\end{array}$ & $\begin{array}{l}\text { BAA- } \\
2109\end{array}$ & $\begin{array}{l}\text { BAA- } \\
2110\end{array}$ & $\begin{array}{l}\text { BAA- } \\
2111\end{array}$ & $\begin{array}{l}\text { BAA- } \\
2112\end{array}$ & $\begin{array}{l}\text { BAA- } \\
2113\end{array}$ & $\begin{array}{l}\text { BAA- } \\
2114\end{array}$ \\
\hline \multirow{3}{*}{ Penicillins } & Amoxicillin/Clavulanic Acid & $\mathrm{R}$ & $\mathrm{R}$ & NT & $\mathrm{R}$ & $\mathrm{R}$ & $\mathrm{R}$ & $\mathrm{R}$ \\
\hline & Piperacillin/Tazobactam & NT & $\mathrm{S}$ & NT & $\mathrm{S}$ & $\mathrm{S}$ & $\mathrm{S}$ & $\mathrm{S}$ \\
\hline & Ampicillin & $\mathrm{R}$ & $\mathrm{R}$ & $\mathrm{R}$ & $\mathrm{R}$ & $\mathrm{R}$ & $\mathrm{R}$ & $\mathrm{R}$ \\
\hline \multirow{9}{*}{ Cephalosporins } & Cefalotin & $\mathrm{R}$ & $\mathrm{R}$ & NT & $\mathrm{R}$ & $\mathrm{R}$ & $\mathrm{R}$ & $\mathrm{R}$ \\
\hline & Cefuroxime & $\mathrm{R}$ & $\mathrm{R}$ & NT & $\mathrm{R}$ & $\mathrm{R}$ & $\mathrm{R}$ & $\mathrm{R}$ \\
\hline & Cefuroxime Axetil & $\mathrm{R}$ & $\mathrm{R}$ & NT & $\mathrm{R}$ & $\mathrm{R}$ & $\mathrm{R}$ & $\mathrm{R}$ \\
\hline & Cefpodoxime & $\mathrm{R}$ & $\mathrm{R}$ & NT & $\mathrm{R}$ & $\mathrm{R}$ & $\mathrm{R}$ & $\mathrm{R}$ \\
\hline & Cefotaxime & $\mathrm{R}$ & $\mathrm{R}$ & $\mathrm{R}$ & $\mathrm{R}$ & $\mathrm{R}$ & $\mathrm{R}$ & $\mathrm{R}$ \\
\hline & Cefazolin & NT & $\mathrm{R}$ & $\mathrm{R}$ & $\mathrm{R}$ & $\mathrm{R}$ & $\mathrm{R}$ & $\mathrm{R}$ \\
\hline & Cefoxitin & $\mathrm{R}$ & $\mathrm{R}$ & $\mathrm{R}$ & $\mathrm{R}$ & $\mathrm{R}$ & $\mathrm{R}$ & $\mathrm{R}$ \\
\hline & Ceftazidime & $\mathrm{S}$ & $\mathrm{S}$ & $\mathrm{S}$ & $\mathrm{S}$ & $S$ & I/R & $\mathrm{S}$ \\
\hline & Ceftriaxone & NT & $\mathrm{R}$ & NT & $\mathrm{R}$ & $\mathrm{R}$ & $\mathrm{R}$ & $\mathrm{R}$ \\
\hline \multirow{2}{*}{ Carbapenems } & Ertapenem & NT & NT & NT & NT & NT & NT & NT \\
\hline & Imipenem & $\mathrm{R}$ & $\mathrm{S}$ & $\mathrm{S}$ & $\mathrm{S}$ & $\mathrm{S}$ & $\mathrm{S}$ & $\mathrm{S}$ \\
\hline Quinolones & Ciprofloxacin & $\mathrm{S}$ & $\mathrm{S}$ & $\mathrm{S}$ & $\mathrm{S}$ & $S$ & $\mathrm{~S}$ & $\mathrm{R}$ \\
\hline \multirow{3}{*}{ Aminoglycosides } & Amikacin & $\mathrm{S}$ & $S$ & $S$ & $S$ & $\mathrm{~S}$ & $S$ & $\mathrm{~S}$ \\
\hline & Gentamicin & 1 & $\mathrm{~S}$ & 1 & $\mathrm{~S}$ & $\mathrm{~S}$ & $\mathrm{~S}$ & $\mathrm{~S}$ \\
\hline & Tobramycin & NT & $\mathrm{S}$ & $\mathrm{S}$ & $\mathrm{S}$ & $\mathrm{S}$ & $\mathrm{S}$ & $\mathrm{S}$ \\
\hline \multirow{4}{*}{ Other } & Tetracycline & $\mathrm{R}$ & $\mathrm{R}$ & $\mathrm{R}$ & $\mathrm{R}$ & $\mathrm{R}$ & $\mathrm{R}$ & $\mathrm{R}$ \\
\hline & Tigecycline & $\mathrm{R}$ & $\mathrm{R}$ & $\mathrm{R}$ & $\mathrm{R}$ & $\mathrm{R}$ & $\mathrm{R}$ & $\mathrm{R}$ \\
\hline & Nitrofurantoin & $\mathrm{R}$ & $\mathrm{R}$ & $\mathrm{R}$ & $\mathrm{R}$ & $\mathrm{R}$ & $\mathrm{R}$ & $\mathrm{R}$ \\
\hline & Trimethoprim/Sulfamethoxazole & $\mathrm{R}$ & $\mathrm{R}$ & $\mathrm{R}$ & $\mathrm{R}$ & $\mathrm{R}$ & $\mathrm{R}$ & $\mathrm{R}$ \\
\hline
\end{tabular}

$\mathrm{R}=$ Resistant; $\mathrm{S}=$ Suspectible; I = Intermediate; NT = Note Tested

Table S1. Antibiotic $P$. aeruginosa Strains Used in this Study. 


\begin{tabular}{|c|c|c|c|c|c|c|c|c|c|}
\hline $\mathrm{J}_{\mathrm{H} 1 \mathrm{H} 2}$ & $\mathrm{~J}_{\mathrm{H} 2 \mathrm{H} 3}$ & $\mathrm{~J}_{\mathrm{H} 3 \mathrm{H} 4}$ & $\mathrm{~J}_{\mathrm{H} 4 \mathrm{H} 5}$ & $\mathrm{~J}_{\mathrm{H} 5 \mathrm{H} 6 \mathrm{a}}$ & $\mathrm{J}_{\mathrm{H} 5 \mathrm{H} 6 \mathrm{~b}}$ & $\mathrm{~J}_{\mathrm{H} 6 \mathrm{aH} 6 \mathrm{~b}}$ & $\mathrm{~J}_{\mathrm{H} 6 \mathrm{H} 7 \mathrm{a}}$ & $\mathrm{J}_{\mathrm{H} 6 \mathrm{H} 7 \mathrm{~b}}$ & $\mathrm{~J}_{\mathrm{H} 7 \mathrm{H} 7 \mathrm{~b}}$ \\
\hline 1.7 & 3.4 & 9.5 & $\sim 9$ & 1.8 & - & - & 7.3 & 5.3 & 11.1 \\
\hline
\end{tabular}

Table S2. ${ }^{3} \mathrm{~J}_{\mathrm{H}-\mathrm{C}-\mathrm{C}-\mathrm{H}}$ coupling constants (Hz) found for 2,4-P-Hep, as determined by $500 \mathrm{MHz}$ Avance Bruker, $10 \mathrm{mM}$ phosphate buffer $\mathrm{pH} 7.2$ with $0.15 \mathrm{M} \mathrm{NaCl}$ and $0.3 \mathrm{mM}$ EDTA-d16 (298K). 


\begin{tabular}{|c|c|c|c|c|}
\hline \multicolumn{2}{|c}{ Selected NOEs } & \multicolumn{3}{c|}{ Mixing time (ms) } \\
\hline \multicolumn{2}{|c|}{ Correlation } & 500 & 800 & 1000 \\
\hline & $\mathrm{H} 1$ & 1.6 & 2.4 & 3.7 \\
& $\alpha \mathrm{CH}_{2} \mathrm{a}$ & 0.6 & 0.8 & 0.9 \\
& $\alpha \mathrm{CH}_{2} \mathrm{~b}$ & 1.4 & 2.3 & 2.2 \\
$\mathrm{H} 2+\mathrm{H} 4$ & $\mathrm{H} 3$ & 2.4 & 3.8 & 4.4 \\
$\mathrm{H} 2+\mathrm{H} 4$ & $\mathrm{H} 5$ & 0.4 & 0.5 & 0.4 \\
& $\mathrm{H} 7 \mathrm{a}$ & 1.3 & 1.1 & 1.2 \\
$\mathrm{H} 3$ & $\mathrm{H} 2+\mathrm{H}_{4}$ & 2.5 & 4.0 & 4.7 \\
& $\mathrm{H} 5$ & 1.6 & 2.9 & 3.0 \\
$\mathrm{H} 5$ & $\mathrm{H} 3$ & 1.8 & 3.1 & 3.5 \\
& $\mathrm{H} 6$ & 1.8 & 2.6 & 3.7 \\
$\alpha \mathrm{CH}_{2} \mathrm{a}$ & $\alpha \mathrm{CH}_{2} \mathrm{~b}$ & 5.8 & 9.2 & 11.8 \\
& $\beta \mathrm{CH}_{2}$ & 2.4 & 2.9 & 2.5 \\
$\alpha \mathrm{CH}_{2} \mathrm{~b}$ & $\alpha \mathrm{CH}_{2} \mathrm{a}$ & 5.9 & 8.5 & 11.4 \\
& $\beta \mathrm{CH}_{2}$ & 2.0 & 3.2 & 3.2 \\
$\varepsilon \mathrm{CH}_{2}$ & $\delta \mathrm{CH}_{2}$ & 2.1 & 3.6 & 3.8 \\
& $\gamma \mathrm{CH}_{2}$ & 0.9 & 1.7 & 1.8 \\
\hline
\end{tabular}

Table S3. Selected intra-residue NOEs\% for Hep-2P,4P at different mixing times (ms). In the case of overlap, most probable correlations are highlighted in bold $600 \mathrm{MHz}$ Avance Bruker, $10 \mathrm{mM}$ phosphate buffer $\mathrm{pH} 7.2$ with $0.15 \mathrm{M} \mathrm{NaCl}$ and $0.3 \mathrm{mM}$ EDTA-d16 (298K) 
Supplementary Methods. Methods of Figure S14 and Synthesis of Glycans

ELISA binding to C1q. Binding to C1q was measured by ELISA. Rituximab and VSX were coated on an ELISA plate at $25 \mu \mathrm{g} / \mathrm{mL}(2.5 \mu \mathrm{g} / \mathrm{well})$ in PBS and stored at $4^{\circ} \mathrm{C}$ overnight. Plates were washed three times with PBST. Purified C1q (Quidel Corporation) was titrated threefold in PBST-BSA from $12.5 \mu \mathrm{g} / \mathrm{mL}$ to $0.02 \mu \mathrm{g} / \mathrm{mL}$ and incubated for 90 minutes at room temperature. Liquid was aspirated from the wells and polyclonal rabbit anti-human C1q was diluted in PBSTBSA to a final concentration of $1 \mu \mathrm{g} / \mathrm{mL}$ and $100 \mu \mathrm{L}$ was added to each well and incubated for 1 hour at room temperature. Plates were washed three times with PBST. Polyclonal swine antirabbit-HRP was diluted to $0.5 \mu \mathrm{g} / \mathrm{mL}$ in PBST-BSA and $100 \mu \mathrm{L}$ was added to each well and incubated for 1 hour at room temperature. The plates were washed six times with PBST and then developed with TMB solution as already described. The values of antibody concentration ( $\mathrm{x}$-axis) and absorbance at $450 \mathrm{~nm}$ (y-axis) were plotted.

Fc $\gamma$ RIIa and FcyRIIb binding by Bio-Layer Interferometry. Binding to Fc $\gamma$ receptors IIa and IIb was measured by BioLayer Interferometry using the Octet QKe system. Briefly, Fc $\gamma I I a$ and Fc $\gamma \mathrm{IIb}$ (R\&D Systems) were diluted to $5 \mu \mathrm{g} / \mathrm{mL}$ in PBS. The receptors were immobilized via a Cterminal 6x histidine tag to Ni-NTA biosensors for 180 seconds followed by a 60 second baseline step in PBS. The biosensors were then exposed to the rituximab and VSX at a concentration of 50 $\mu \mathrm{g} / \mathrm{mL}$ in PBS for 120 seconds followed by a dissociation step in PBS for an additional 120 seconds. The binding response was measured and reported in the form of a sensorgram trace.

General Synthetic Methods. All reagents, solvents (ACS grade or anhydrous) were used as purchased from Sigma-Aldrich, Alfa-Aeser and Corden Pharma Company without further purification or drying. TLC plates were purchased from Merck Millipore. Sephadex G-10 was purchased from GE Healthcare Life Sciences. Sulfo-NHS-LC-LC-Biotin (cat \#: 21338) was purchased from Thermo Fisher Scientific Company. Solvents used for extraction and flash chromatography were ACS grade. Air free reactions were carried out by simplified Schlenk operation: vacuum- $\mathrm{N}_{2}$ gas balloon technique. Flash column chromatography was performed on Teledyne ISCO CombiFlash system equipped with Redisep Gold or regular silica gel columns. ${ }^{1} \mathrm{H}-\mathrm{NMR}$ and ${ }^{13} \mathrm{C}-\mathrm{NMR}$ spectra were obtained on 300,400 or $500 \mathrm{MHz}$ Varian ${ }^{\circledR}$ FT-NMR spectrometers of the Department of Chemistry Instrumentation Facility (DCIF) at the Massachusetts Institute of Technology (MIT), with special thanks to the National Science Foundation for their generous financial support; without their continuing support, the DCIF would not be able to supply the MIT and surrounding scientific communities with the level of support needed to maintain this state-of-the-art facility. Mass spectra were obtained using electrospray ionization using an Agilent 1100 Single Quadrupole LC-MS instrument. 

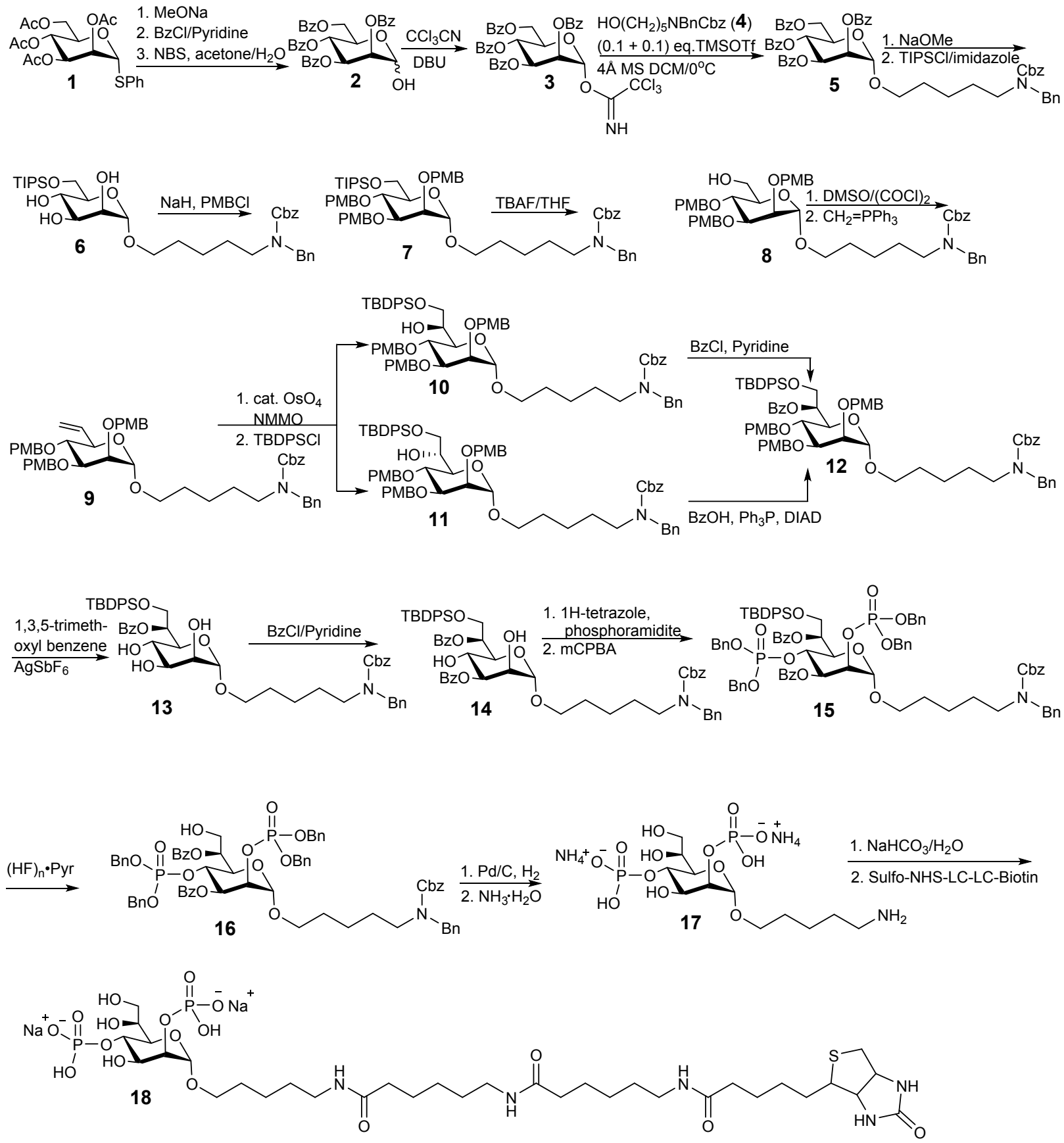

Supplementary Scheme 1. Synthesis of 2,4-diphosphorylated L-glycero-D-mannoheptose-LC-LC-Biotin. 

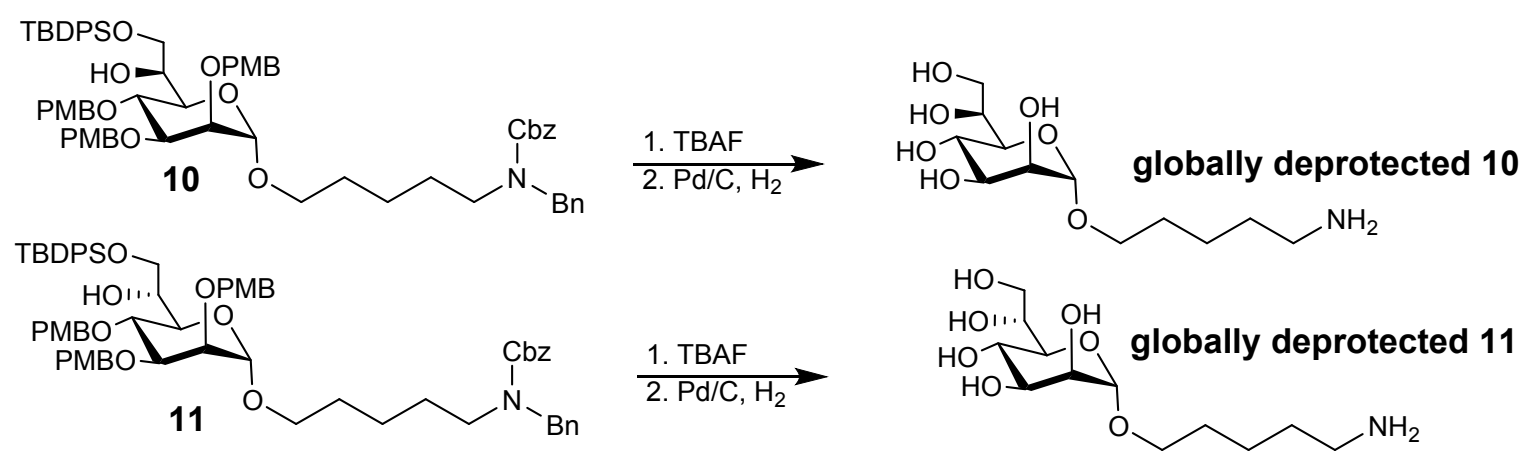

Supplementary Scheme 2. Determination of stereochemistry by comparison of ${ }^{1} \mathrm{H}-\mathrm{NMR}$ of deprotected compounds with that of known compounds.
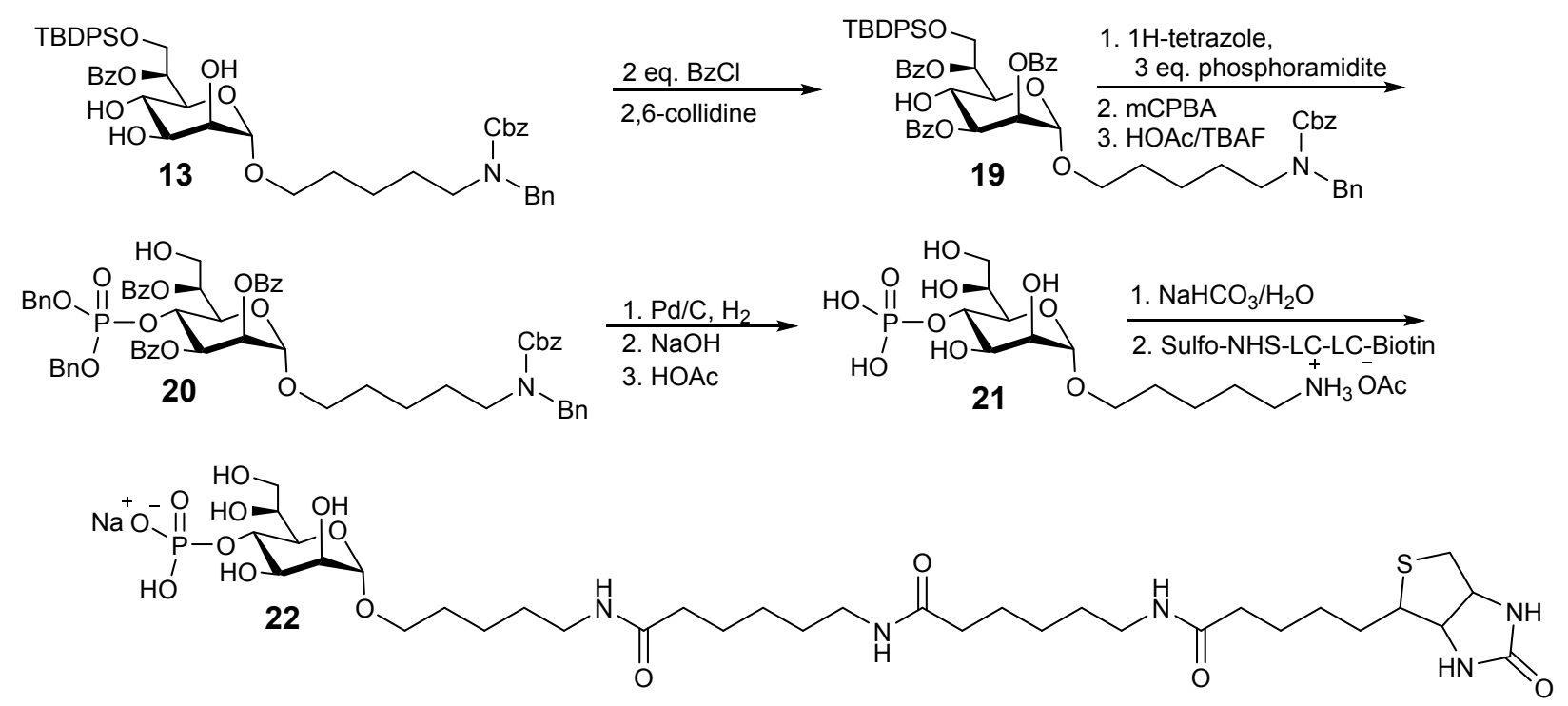

Supplementary Scheme 3. Synthesis of 4-phosphorylated L-glycero-D-mannoheptose-LC-LC-Biotin. 


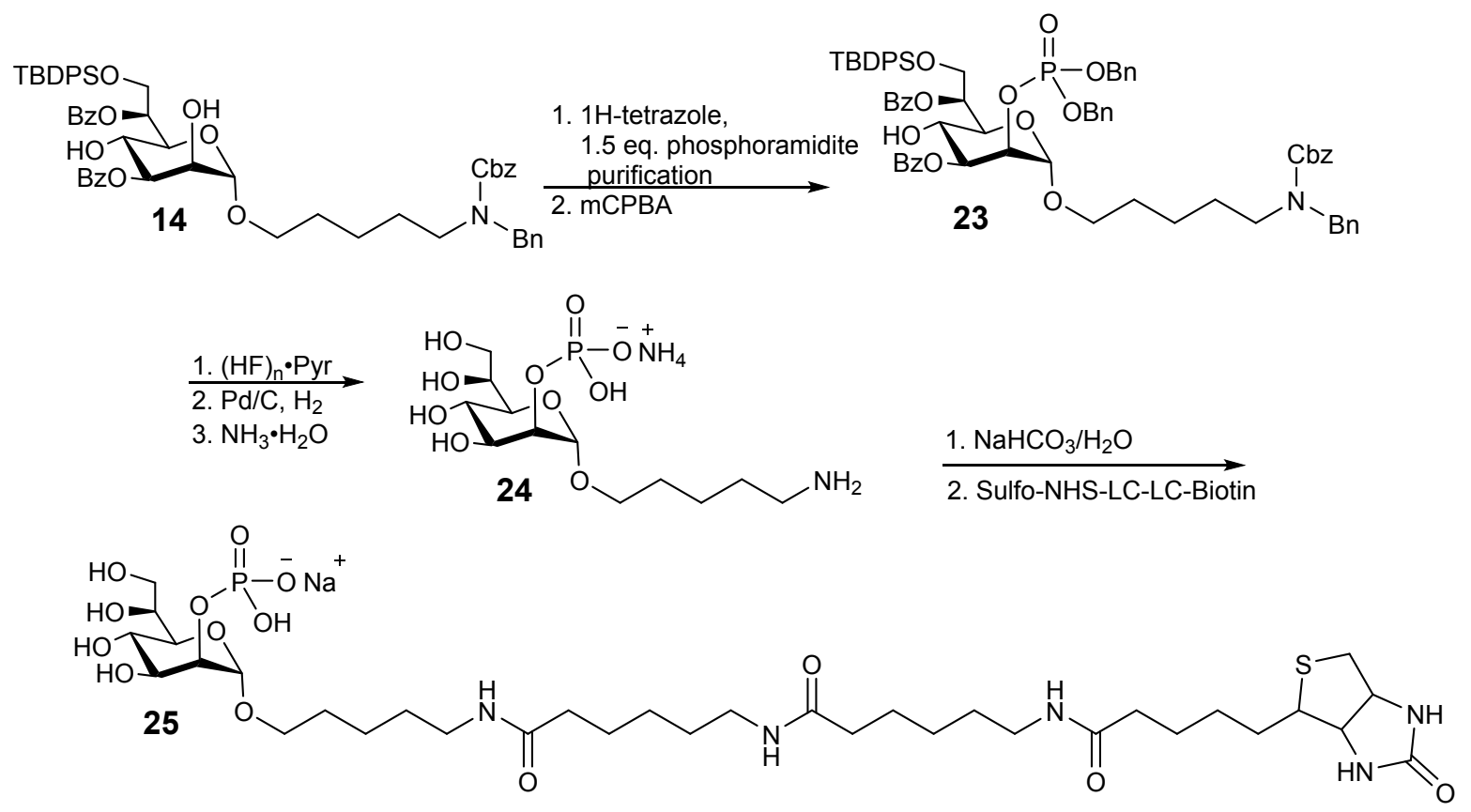

Supplementary Scheme 4. Synthesis of 2-phosphorylated L-glycero-D-mannoheptose-LC-LC-Biotin.

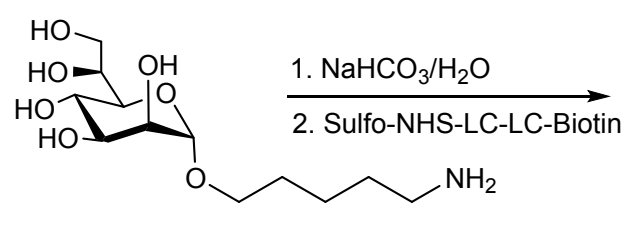

globally deprotected 10

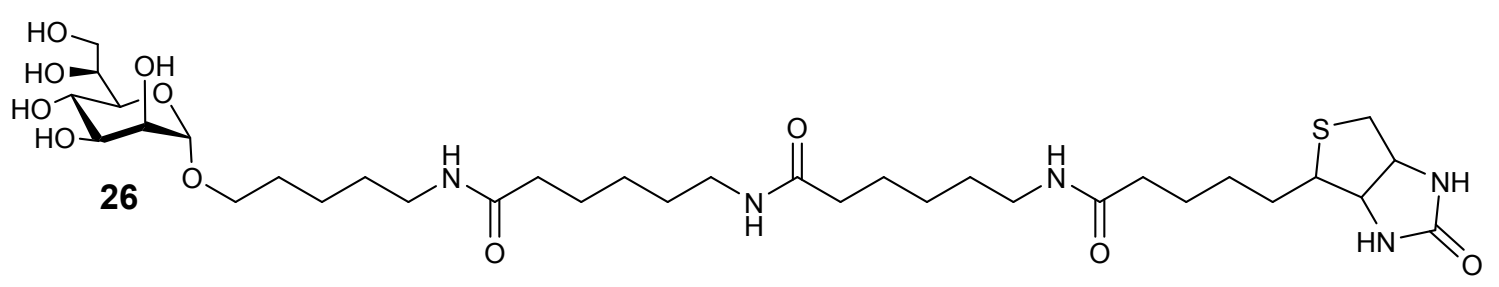

Supplementary Scheme 5. Synthesis of $L$-glycero-D-mannoheptose-LC-LC-Biotin. 

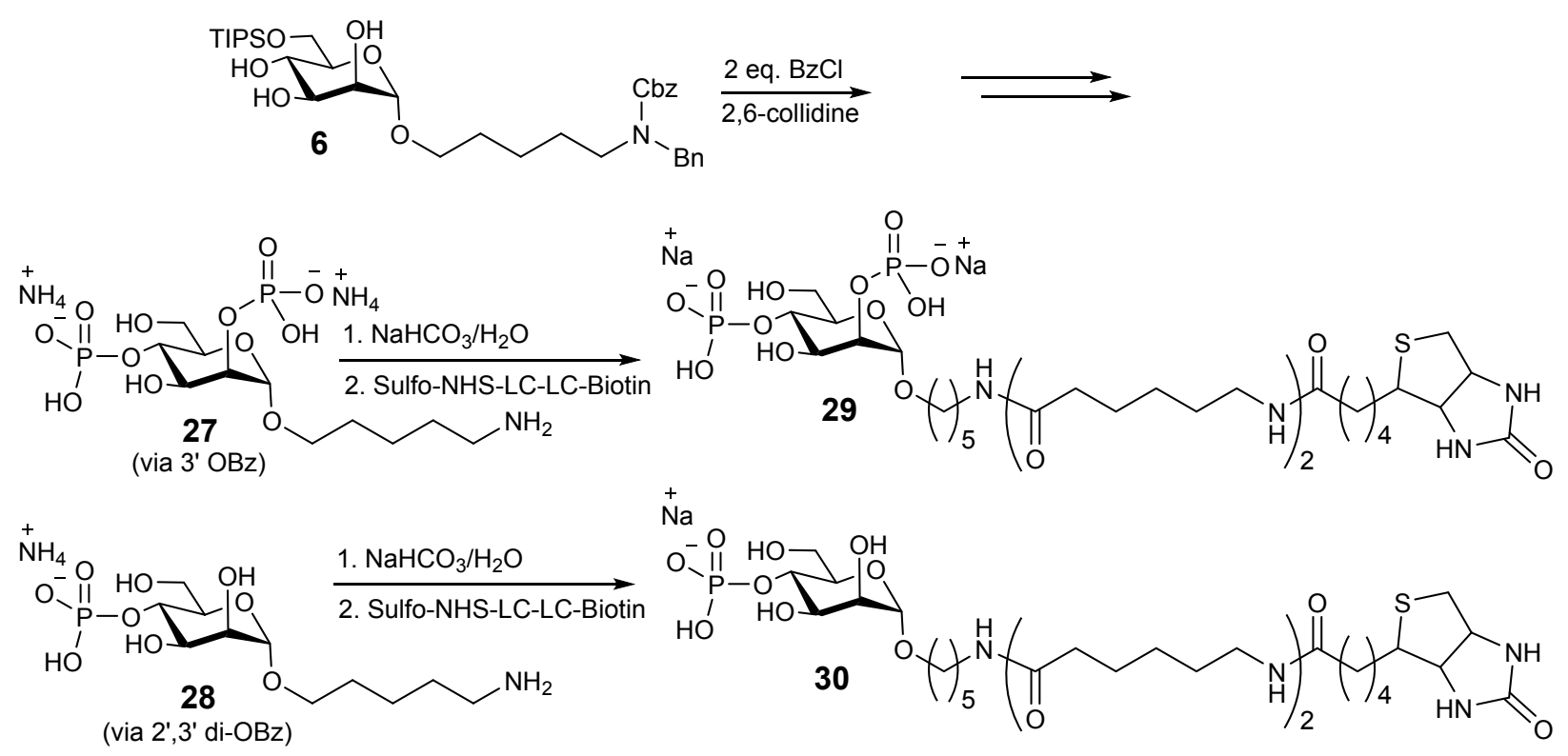

Supplementary Scheme 6. Synthesis of 2,4-diphophorylated D-mannose-LC-LC-Biotin and 4-phosphorylated $D$-mannose-LC-LC-Biotin.
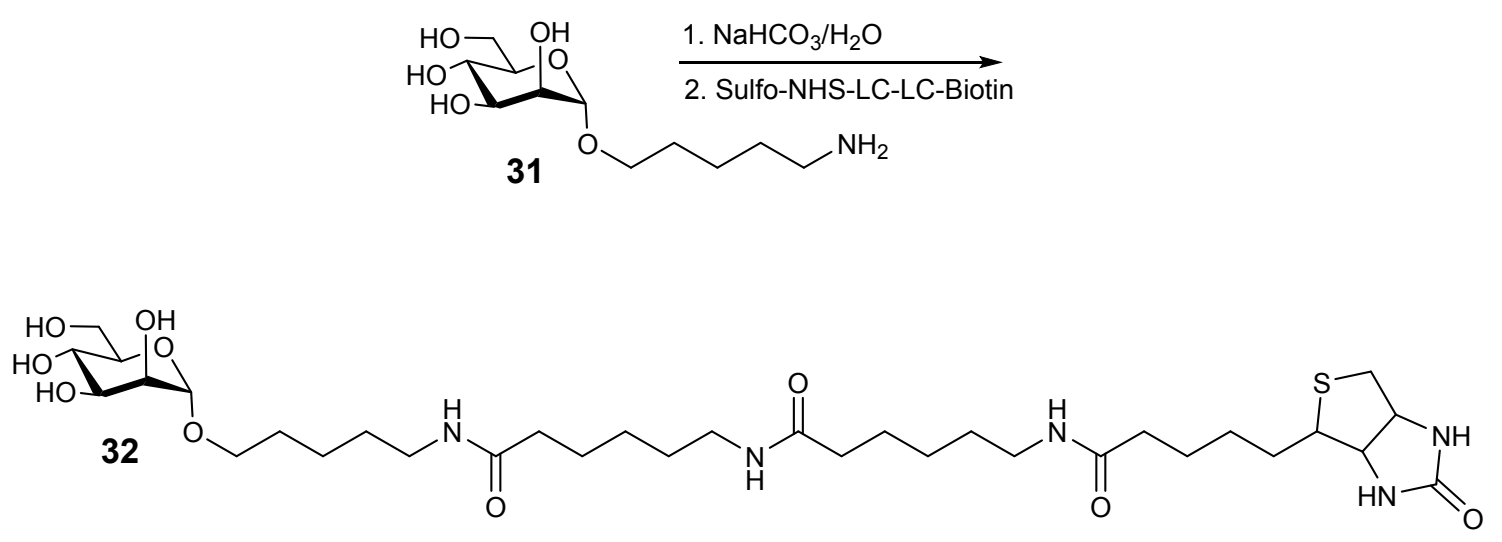

Supplementary Scheme 7. Synthesis of L-glycero-D-mannose-LC-LC-Biotin. 


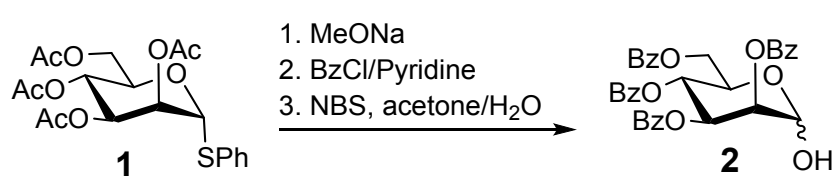

Synthesis of 2. To the solution of commercial tetraacetate mannoside $1(11 \mathrm{~g}, 25 \mathrm{mmol})$ in anhydrous $\mathrm{MeOH}(125 \mathrm{~mL})$ was added $\mathrm{NaOMe}(0.5 \mathrm{M}$ in $\mathrm{MeOH}, 25 \mathrm{~mL}, 12.5 \mathrm{mmol})$ at $0{ }^{\circ} \mathrm{C}$ under $\mathrm{N}_{2}$ atmosphere. After stirring was continued for 3.5 hours at $\mathrm{rt}$ (TLC monitoring showed complete conversion), the $\mathrm{pH}$ of the reaction mixture was adjusted to 5-6 with careful addition of resin (Amberlite ${ }^{\circledR}$ IR120 H form). After removal of resin with filtration, the filtrate was concentrated by rotovap to provide the intermediate $(7.1 \mathrm{~g}$, quantitative) deemed pure enough for the next step. This intermediate was co-evaporated with ethyl acetate (200 $\mathrm{mL} \mathrm{x} \mathrm{3)} \mathrm{to} \mathrm{remove} \mathrm{residual} \mathrm{MeOH}$, and was dissolved $(6.8 \mathrm{~g}, 25 \mathrm{mmol})$ in dry dichloromethane (150 $\mathrm{mL})$ to which was added pyridine $(30.2 \mathrm{~mL}, 375 \mathrm{mmol})$, 4-dimethylaminopyridine (305 $\mathrm{mg}, 2.5 \mathrm{mmol})$, then benzoyl chloride $(23.2 \mathrm{~mL}, 200 \mathrm{mmol})$ dropwise at $0{ }^{\circ} \mathrm{C}$. The stirring was continued overnight, after the reaction was allowed to warm up to rt. Methanol $(15 \mathrm{~mL})$ was then added and stirring was continued for 1 hour at $\mathrm{rt}$ to ensure complete consumption of benzoyl chloride. The reaction mixture was transferred into a separation funnel and washed with $\mathrm{HCl}(1 \mathrm{~N}, 100 \mathrm{~mL} \times 3)$. The organic phase was separated, dried over anhydrous $\mathrm{Na}_{2} \mathrm{SO}_{4}$, filtered and concentrated by rotovap to provide the intermediate in quantitative yield. To the solution of this intermediate in acetone/water $(10 / 1,220 \mathrm{~mL})$ was added NBS $(7.5 \mathrm{~g}, 42.4$ $\mathrm{mmol})$ at $0{ }^{\circ} \mathrm{C}$ portion-wise. After stirring was continued for $30 \mathrm{~min}$ at $0{ }^{\circ} \mathrm{C}$ and $30 \mathrm{~min}$ at $\mathrm{rt}$, NBS $(7.5 \mathrm{~g}$, $42.4 \mathrm{mmol}$ ) was again added portion-wise. After stirring was continued for $30 \mathrm{~min}$ at $0{ }^{\circ} \mathrm{C}$ and $30 \mathrm{~min}$ at rt, TLC showed complete conversion. The residue from concentration by rotovap was redissolved in ethyl acetate $\left(200 \mathrm{~mL}\right.$ ), and washed with $\mathrm{NaHCO}_{3}$ (saturated aqueous, $100 \mathrm{~mL}$ ). Separation, drying over anhydrous $\mathrm{Na}_{2} \mathrm{SO}_{4}$, filtration and concentration by rotovap provided crude product. Purification of crude product by silica gel chromatography ( $15 \%$ ethyl acetate in hexane, then $25 \%$ ethyl acetate in hexane) gave product 2 ( $13 \mathrm{~g}, 88 \%$ isolated yield). The ${ }^{1} \mathrm{H}$ NMR is consistent with the literature ${ }^{1}$. ${ }^{1} \mathrm{H}$ NMR (300 MHz, Chloroform-d) $\delta 8.17-7.77(\mathrm{~m}, 8 \mathrm{H}), 7.67-7.15(\mathrm{~m}, 12 \mathrm{H}), 6.17(\mathrm{t}, J=10.1 \mathrm{~Hz}, 1 \mathrm{H}), 6.08-5.95(\mathrm{~m}, 1 \mathrm{H})$, $5.78-5.64(\mathrm{~m}, 1 \mathrm{H}), 5.53(\mathrm{~d}, J=1.9 \mathrm{~Hz}, 1 \mathrm{H}), 4.77(\mathrm{dd}, J=12.0,3.0 \mathrm{~Hz}, 1 \mathrm{H}), 4.67(\mathrm{dt}, J=12.0,3.0 \mathrm{~Hz}$, 1H), 4.45 (dd, $J=12.0,3.0 \mathrm{~Hz}, 1 \mathrm{H}), 3.48$ (broad, 1H).

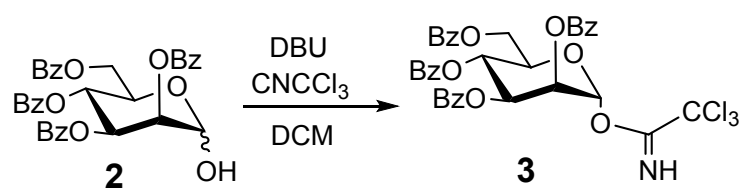

Synthesis of 3. To the solution of $2(1 \mathrm{~g}, 1.7 \mathrm{mmol})$ in dry DCM $(10 \mathrm{~mL})$ was added trichloroacetonitrile $(0.84 \mathrm{~mL}, 8.3 \mathrm{mmol})$, then diazabicycloundecene $(25 \mathrm{mg}, 0.17 \mathrm{mmol})$ at $0{ }^{\circ} \mathrm{C}$ under $\mathrm{N}_{2}$ atmosphere. After stirring was continued for $5 \mathrm{~min}$ at $0{ }^{\circ} \mathrm{C}$, then for 1 hour at rt, the reaction mixture was concentrated to about $3 \mathrm{~mL}$, then directly loaded on a silica gel column (equilibrated with $0.5 \% \mathrm{Et}_{3} \mathrm{~N}$ in hexane before sample loading). Elution with $25 \%$ of ethyl acetate in hexane (containing $0.5 \% \mathrm{Et}_{3} \mathrm{~N}$ ) gave product $3(800 \mathrm{mg}$, $67 \%$ isolated yield). ${ }^{1} \mathrm{H}-\mathrm{NMR}$ is consistent with the reported data ${ }^{2} .{ }^{1} \mathrm{H}$ NMR (300 MHz, Chloroform- $d$ ) $\delta$ $8.86(\mathrm{~s}, 1 \mathrm{H}), 8.08(\mathrm{~m}, 4 \mathrm{H}), 7.96(\mathrm{~m}, 2 \mathrm{H}), 7.84(\mathrm{~m}, 2 \mathrm{H}), 7.68-7.09(\mathrm{~m}, 12 \mathrm{H}), 6.57(\mathrm{~d}, J=1.8 \mathrm{~Hz}, 1 \mathrm{H}), 6.23$ $(\mathrm{t}, J=9.0 \mathrm{~Hz}, 1 \mathrm{H}), 5.99(\mathrm{~d}, 3.0 \mathrm{~Hz}, 1 \mathrm{H}), 5.95(\mathrm{~m}, 1 \mathrm{H}), 4.73(\mathrm{dd}, J=12.0,3.0 \mathrm{~Hz}, 1 \mathrm{H}), 4.63(\mathrm{~m}, 1 \mathrm{H}), 4.52$ $(\mathrm{dd}, J=12.0,3.0 \mathrm{~Hz}, 1 \mathrm{H})$.

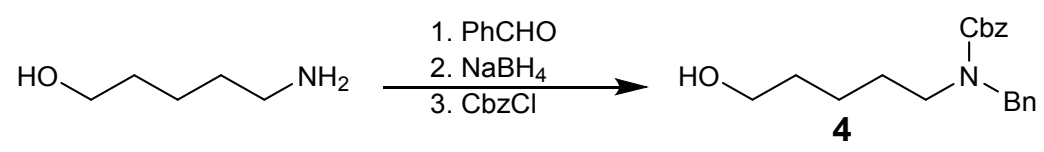

Synthesis of 4. $\mathrm{HO}\left(\mathrm{CH}_{2}\right)_{5} \mathrm{NBnCbz}(4)$ was made from $\mathrm{HO}\left(\mathrm{CH}_{2}\right)_{5} \mathrm{NH}_{2}$ using a procedure described in the literature ${ }^{3}$. ${ }^{1} \mathrm{H}$ NMR $(300 \mathrm{MHz}$, Chloroform- $d) \delta 7.37(\mathrm{~m}, 10 \mathrm{H}), 5.25(\mathrm{~d}, J=8.6 \mathrm{~Hz}, 2 \mathrm{H}), 4.57(\mathrm{~d}, J=5.4$ 
$\mathrm{Hz}, 2 \mathrm{H}), 3.62(\mathrm{dt}, J=18.3,6.6 \mathrm{~Hz}, 2 \mathrm{H}), 3.32(\mathrm{dt}, J=21.3,7.4 \mathrm{~Hz}, 2 \mathrm{H}), 2.42$ (broad, 1H), $1.62(\mathrm{~m}, 4 \mathrm{H})$, $1.37(\mathrm{~m}, 2 \mathrm{H})$.
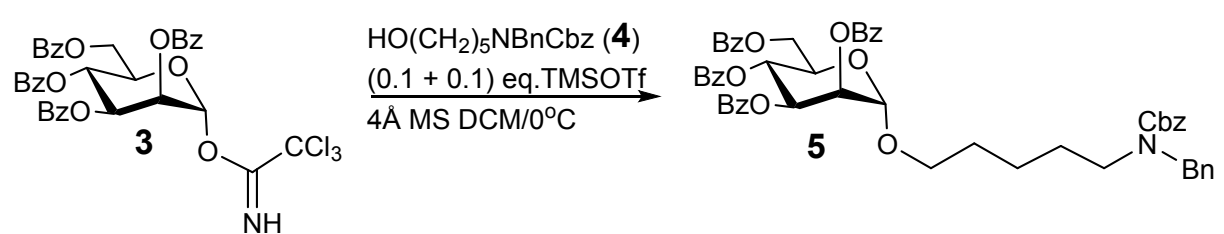

Synthesis of 5. The mixture of $3(8.7 \mathrm{~g}, 11.7 \mathrm{mmol})$ and $\mathbf{4}(8.7 \mathrm{~g}, 25.8 \mathrm{mmol})$ was co-evaporated with toluene (ACS grade, $50 \mathrm{~mL}$, then anhydrous toluene $50 \mathrm{ml}$ x 2). Another reaction flask charged with molecular sieves ( $4 \AA$, powdered from beads, $8.7 \mathrm{~g}$ ) was flame/vacuum dried, then cooled to rt under $\mathrm{N}_{2}$ atmosphere. The mixture of $\mathbf{3}$ and $\mathbf{4}$ was transferred into the cooled reaction flask charged with molecular sieves with dry dichloromethane $(60 \mathrm{~mL})$ and stirring was continued for $30 \mathrm{~min}$ at $\mathrm{rt}$. The reaction flask was then cooled down with an ice-water bath. To the reaction mixture was added neat trimethylsilyl trifluoromethanesulfonate $(0.21 \mathrm{~mL}, 1.17 \mathrm{mmol})$ dropwise by syringe. After stirring was continued for 30 min at $0{ }^{\circ} \mathrm{C}$, another portion of neat trimethylsilyl trifluoromethanesulfonate $(0.21 \mathrm{~mL}, 1.17 \mathrm{mmol})$ was added dropwise by syringe. After stirring was continued for $40 \mathrm{~min}$ at $0{ }^{\circ} \mathrm{C}$, triethylamine $(1.6 \mathrm{~mL}, 11.7$ $\mathrm{mmol}$ ) was added at $0{ }^{\circ} \mathrm{C}$. Stirring was continued for $5 \mathrm{~min}$ at $\mathrm{rt}$, after which the solvent was filtered and concentrated by rotovap to provide the residue which was purified by silica gel chromatography ( $25 \%$ ethyl acetate in hexane) to provide product 5 (7.6 g, 73\% isolated yield). ${ }^{1} \mathrm{H}$ NMR (300 MHz, Chloroform- $d$ ) $\delta$ $8.09-8.03(\mathrm{~m}, 4 \mathrm{H}), 7.95(\mathrm{~d}, J=7.7 \mathrm{~Hz}, 2 \mathrm{H}), 7.88-7.78(\mathrm{~m}, 2 \mathrm{H}), 7.65-7.23(\mathrm{~m}, 22 \mathrm{H}), 6.09$ (t, $J=10.1$ $\mathrm{Hz}, 1 \mathrm{H}), 5.89$ (dd, $J=10.2,3.3 \mathrm{~Hz}, 1 \mathrm{H}), 5.67(\mathrm{~s}, 1 \mathrm{H}), 5.19(\mathrm{~d}, J=11.7 \mathrm{~Hz}, 2 \mathrm{H}), 5.04(\mathrm{~m}, 1 \mathrm{H}), 4.68(\mathrm{dd}, J$ $=12.1,2.5 \mathrm{~Hz}, 1 \mathrm{H}), 4.52(\mathrm{~s}, 2 \mathrm{H}), 4.53-4.35(\mathrm{~m}, 2 \mathrm{H}), 3.74(\mathrm{~m}, 2 \mathrm{H}), 3.51(\mathrm{~m}, 1 \mathrm{H}), 3.27(\mathrm{~m}, 2 \mathrm{H}), 1.58(\mathrm{~m}$, $4 \mathrm{H}), 1.32(\mathrm{~m}, 2 \mathrm{H})$.

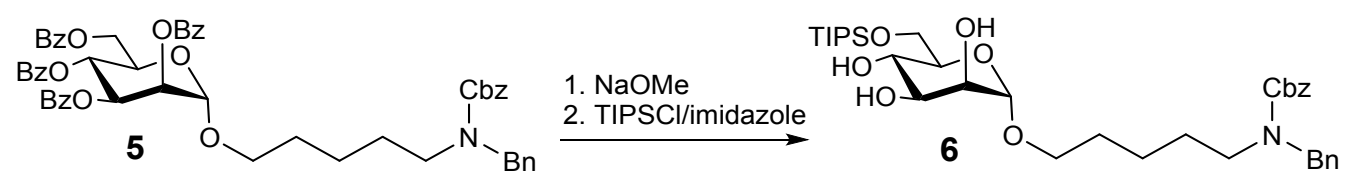

Synthesis of 6. To the solution of 5 (906 mg, $1 \mathrm{mmol}$ ) in $\mathrm{MeOH}$ (ACS grade, $8 \mathrm{~mL}$ ) was added MeONa $(0.5 \mathrm{M}$ in $\mathrm{MeOH}, 1 \mathrm{~mL}, 0.5 \mathrm{mmol})$ at $0{ }^{\circ} \mathrm{C}$ under $\mathrm{N}_{2}$ atmosphere. After stirring was continued for 3 hours at $\mathrm{rt}$ (TLC showed complete conversion), the $\mathrm{pH}$ of the reaction mixture was adjusted to 5-6 with careful addition of resin (Amberlite ${ }^{\circledR}$ IR120 H form). The filtrate was concentrated by rotovap after removing resin with filtration to provide the intermediate ( $7.1 \mathrm{~g}$, quantitative) which is pure enough for the next step. To the solution of $7.1 \mathrm{~g}$ crude intermediate in dry dichloromethane $(6 \mathrm{~mL})$, was added imidazole $(231 \mathrm{mg}$, $3.4 \mathrm{mmol})$, then triisopropylsilyl chloride $(0.36 \mathrm{~mL}, 1.7 \mathrm{mmol})$ at $0{ }^{\circ} \mathrm{C}$ under $\mathrm{N}_{2}$ atmoshpere. After stirring was continued for 3 hours at $\mathrm{rt}$, imidazole $(165 \mathrm{mg}, 1.7 \mathrm{mmol})$, then triisopropylsilyl chloride $(0.18 \mathrm{~mL}$, $0.85 \mathrm{mmol}$ ) was added. TLC monitoring showed complete conversion after stirring was continued for 2 hours at rt. The reaction solvent was removed by rotovap, and the residue was redissolved in ethyl acetate $(20 \mathrm{~mL})$, washed with $\mathrm{HCl}\left(1 \mathrm{~N}, 10 \mathrm{~mL}\right.$ x 2) and brine, separated, dried over $\mathrm{Na}_{2} \mathrm{SO}_{4}$, filtered and concentrated with rotavap. The new residue was purified using silica gel chromatography to provide product 6 (590 mg, 91\% isolated yield over two steps). ${ }^{1} \mathrm{H}$ NMR (300 MHz, Chloroform- $d$ ) $\delta 7.37-7.16$ $(\mathrm{m}, 10 \mathrm{H}), 5.18(\mathrm{~d}, J=9 \mathrm{~Hz}, 2 \mathrm{H}), 4.77(\mathrm{~m}, 1 \mathrm{H}), 4.49(\mathrm{~m}, 2 \mathrm{H}), 4.01-3.76(\mathrm{~m}, 5 \mathrm{H}), 3.63(\mathrm{~m}, 2 \mathrm{H}), 3.37(\mathrm{~m}$, 1H), 3.22 (m, 2H). 


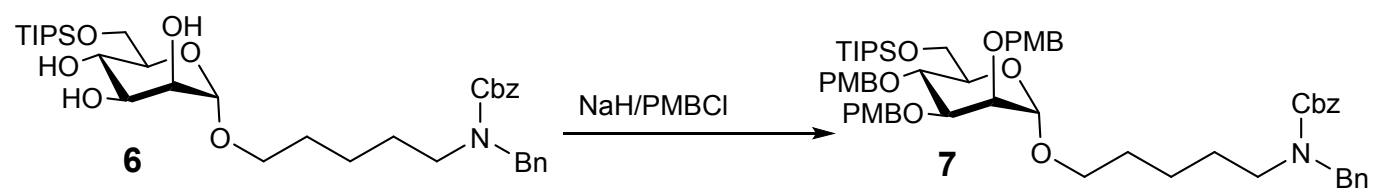

Synthesis of 7. Compound 6 was co-evaporated with toluene (ACS grade $10 \mathrm{~mL}$, dry toluene $10 \mathrm{~mL}$ ). To the solution of $6(0.98 \mathrm{~g}, 1.5 \mathrm{mmol})$ in dry DMF $(10 \mathrm{~mL})$, was added 4-methoxybenzyl chloride $(1 \mathrm{~mL}, 7.5$ $\mathrm{mmol})$, then $\mathrm{NaH}(60 \%$ in mineral oil, $240 \mathrm{mg}, 6 \mathrm{mmol})$ at $0{ }^{\circ} \mathrm{C}$ under $\mathrm{N}_{2}$ atmosphere. Stirring was continued overnight, while the reaction was allowed to warm up to rt. Hexane/ethyl acetate $(2 / 1,100 \mathrm{~mL})$ followed by distilled water $(20 \mathrm{~mL})$ were added to the reaction mixture with vigorous stirring. The organic phase was separated and washed with brine, dried over anhydrous $\mathrm{Na}_{2} \mathrm{SO}_{4}$, filtered and concentrated by rotovap. The residue was purified by silica gel chromatography $(10 \%$ ethyl acetate in hexane, then $15 \%$ ethyl acetate in hexane) to provide product 7 (801 mg, 53\% isolated yield). ${ }^{1} \mathrm{H}$ NMR (300 $\mathrm{MHz}$, Chloroform- $d$ ) $\delta 7.26(\mathrm{~m}, 16 \mathrm{H}), 6.8(\mathrm{~m}, 6 \mathrm{H}), 5.17(\mathrm{~d}, J=6.0 \mathrm{~Hz}, 2 \mathrm{H}), 4.82(\mathrm{~d}, J=9.0 \mathrm{~Hz}, 1 \mathrm{H}), 4.72(\mathrm{~s}$, $1 \mathrm{H}), 4.63(\mathrm{~m}, 2 \mathrm{H}), 4.55(\mathrm{~s}, 2 \mathrm{H}), 4.49(\mathrm{~m}, 2 \mathrm{H}), 3.88(\mathrm{~m}, 1 \mathrm{H}), 3.80(\mathrm{~s}, 9 \mathrm{H}), 3.57(\mathrm{~m}, 2 \mathrm{H}), 3.23(\mathrm{~m}, 2 \mathrm{H}), 1.48$ $(\mathrm{m}, 4 \mathrm{H}), 1.24(\mathrm{~m}, 2 \mathrm{H}), 1.10(\mathrm{~m}, 3 \mathrm{H}), 1.05(\mathrm{~s}, 18 \mathrm{H})$.

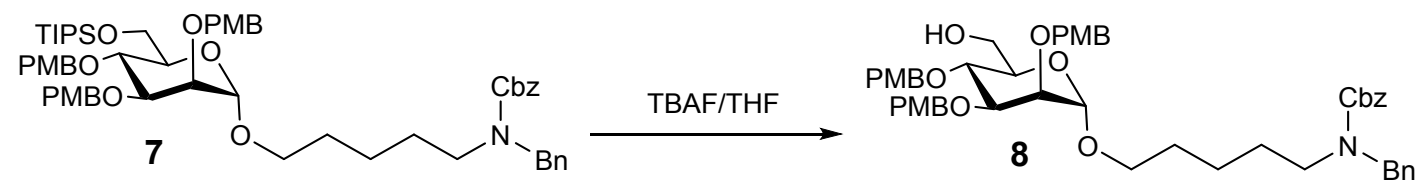

Synthesis of 8. To the solution of $7(780 \mathrm{mg}, 0.77 \mathrm{mmol})$ in dry THF $(3 \mathrm{~mL})$ was added tetrabutylammonium fluoride ( $1 \mathrm{M}$ in THF, $1.5 \mathrm{~mL}, 1.5 \mathrm{mmol}$ ) at $\mathrm{rt}$ under $\mathrm{N}_{2}$ atmosphere. After stirring was continued at $\mathrm{rt}$ for 2.5 hours, the solvent was removed by rotovap. The resulting residue was redissolved in ethyl acetate $(20 \mathrm{~mL})$, washed with aqueous $\mathrm{NH}_{4} \mathrm{Cl}$ (sat.), separated, dried over anhydrous $\mathrm{Na}_{2} \mathrm{SO}_{4}$, filtered and concentrated by rotovap. This resulting residue was purified by silica gel chromatography ( $40 \%$ of ethyl acetate in hexane) to provide product $8\left(580 \mathrm{mg}, 88 \%\right.$ isolated yield). ${ }^{1} \mathrm{H}$ NMR (300 MHz, Chloroform- $d$ ) $\delta 7.28(\mathrm{~m}, 16 \mathrm{H}), 6.85(\mathrm{~m}, 6 \mathrm{H}), 5.16(\mathrm{~d}, J=6.0 \mathrm{~Hz}, 2 \mathrm{H}), 4.84(\mathrm{~d}, J=12.0$ $\mathrm{H}, 1 \mathrm{H}), 4.70-4.49,(\mathrm{~m}, 5 \mathrm{H}), 4.56(\mathrm{~s}, 2 \mathrm{H}), 3.85(\mathrm{~m}, 1 \mathrm{H}), 3.79(\mathrm{~s}, 9 \mathrm{H}), 3.58(\mathrm{~m}, 2 \mathrm{H}), 3.25(\mathrm{~m}, 2 \mathrm{H}), 1.53(\mathrm{~m}$, $4 \mathrm{H}), 1.25(\mathrm{~m}, 2 \mathrm{H})$.
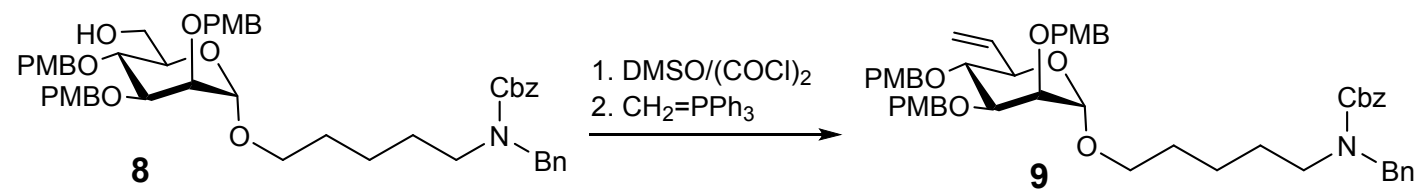

Synthesis of 9. Compound $\mathbf{8}(3.5 \mathrm{~g}, 4.1 \mathrm{mmol})$ was co-evaporated with dry toluene (10 $\mathrm{mL} \times 2)$. Separately, to another dry reaction flask was added dichloromethane $(20 \mathrm{~mL})$, then oxalyl chloride $(0.72 \mathrm{~mL}, 8.16$ $\mathrm{mmol})$ at $-78{ }^{\circ} \mathrm{C}$ under $\mathrm{N}_{2}$ atmosphere. A solution of DMSO $(1.44 \mathrm{~mL}, 20.4 \mathrm{mmol})$ in dry dichloromethane $(1 \mathrm{~mL})$ was then added dropwise at $-78^{\circ} \mathrm{C}$ under $\mathrm{N}_{2}$ atmosphere. After stirring was continued for $15 \mathrm{~min}$ at $-78^{\circ} \mathrm{C}$, compound $8(3.5 \mathrm{~g}, 4.1 \mathrm{mmol})$ in dry dichloromethane $(5 \mathrm{~mL}+5 \mathrm{~mL})$ was added slowly along the inside wall of the flask by syringe. After stirring was continued at $-78^{\circ} \mathrm{C}$ for 1 hour, triethylamine $(3.4$ $\mathrm{mL}$ ) was added dropwise along the inside wall of the flask. After stirring was continued for 1 hour at -78 ${ }^{\circ} \mathrm{C}$, the reaction was allowed to slowly warm to rt over 1 hour. Distilled water $(10 \mathrm{~mL})$ was then added with vigorous stirring. The dichloromethane phase was separated, dried over anhydrous $\mathrm{Na}_{2} \mathrm{SO}_{4}$, filtered, and concentrated by rotovap. The resulting residue was co-evaporated with dry toluene $(50 \mathrm{~mL} \times 2)$ for the next step. Another dry $250 \mathrm{~mL}$ round-bottomed flask was charged with methyltriphenylphosphonium bromide $(3.74 \mathrm{~g}, 10.5 \mathrm{mmol})$, then dry THF $(50 \mathrm{~mL})$. After cooling this reaction flask in an acetone/dry 
ice bath, $n$-BuLi (1.6 M in hexane, $6.0 \mathrm{~mL}, 9.52 \mathrm{mmol}$ ) was added dropwise, at which point the solution became yellow. During stirring for 1.5 hours, the temperature of the cold bath was allowed to increase from $-78^{\circ} \mathrm{C}$ to $0^{\circ} \mathrm{C}$, and the mixture was further stirred for $30 \mathrm{~min}$ at rt. After cooling the resulting ylide in an ice/water bath, the pre-dried aldehyde of $\mathbf{8}$ from the Swern oxidation was added as a dry THF solution in two portions $(3 \mathrm{~mL}+2 \mathrm{~mL})$ along the inside wall of the ylide flask. After stirring was continued for 4 hours at $0{ }^{\circ} \mathrm{C}$, hexane $(100 \mathrm{~mL})$ was added with vigorous stirring and white precipitate crashed out of solution. After filtration over Celite, the filtrate was concentrated by rotovap. The resulting residue was purified by silica gel chromatography $(20 \%$, then $25 \%$ of ethyl acetate in hexane) to provide product $9(2.7$ g, 66\% isolated yield). ${ }^{1} \mathrm{H}$ NMR $(300 \mathrm{MHz}$, Chloroform- $d$ ) $\delta 7.28(\mathrm{~m}, 16 \mathrm{H}), 6.84(\mathrm{~m}, 6 \mathrm{H}), 5.98(\mathrm{~m}, 1 \mathrm{H})$, $5.41(\mathrm{~d}, J=15.0 \mathrm{~Hz}, 1 \mathrm{H}), 5.26(\mathrm{~d}, J=12.0 \mathrm{~Hz}, 1 \mathrm{H}), 5.16(\mathrm{~d}, J=6.0 \mathrm{~Hz}, 2 \mathrm{H}), 4.75-4.47(\mathrm{~m}, 5 \mathrm{H}), 4.71(\mathrm{~s}$, 2H), $3.95(\mathrm{t}, J=6.0 \mathrm{~Hz}, 1 \mathrm{H}), 3.84(\mathrm{~s}, 9 \mathrm{H}), 3.79-3.50(\mathrm{~m}, 2 \mathrm{H}), 3.24(\mathrm{~m}, 2 \mathrm{H}), 1.46(\mathrm{~m}, 4 \mathrm{H}), 1.23(\mathrm{~m}, 2 \mathrm{H})$.

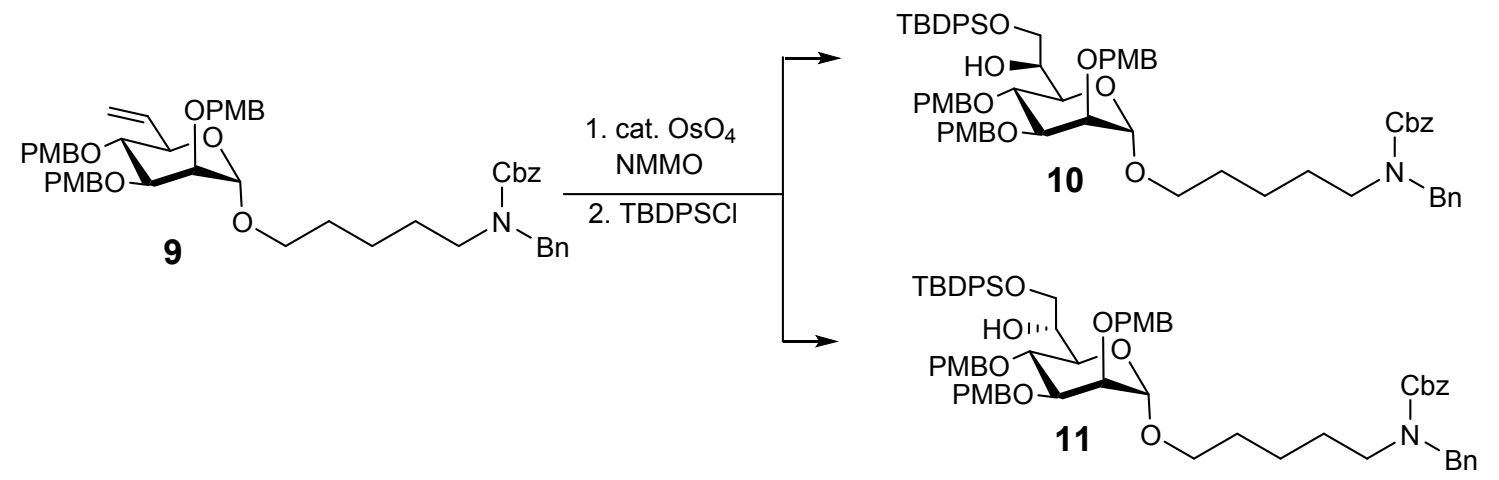

Synthesis of 10 and 11. To the solution of $9(2.7 \mathrm{~g}, 3.24 \mathrm{mmol})$ in acetone/water $(121.5 / 13.5 \mathrm{~mL})$ was added $N$-methylmorpholine oxide $(50 \mathrm{w} \%$ in water, $1.6 \mathrm{~mL}, 6.8 \mathrm{mmol})$, then $\mathrm{OsO}_{4}(2.5 \mathrm{w} \%$ in $t$ - $\mathrm{BuOH}, 4.1$ $\mathrm{mL}, 0.3 \mathrm{mmol}$ ) dropwise with stirring at $0{ }^{\circ} \mathrm{C}$. Stirring was continued for 2 hours at $0{ }^{\circ} \mathrm{C}$, then for 2 hours at $\mathrm{rt}$, after which the reaction was quenched by adding ethyl acetate $(200 \mathrm{~mL})$, then $\mathrm{Na}_{2} \mathrm{~S}_{2} \mathrm{O}_{3}(10 \mathrm{w} \%$ in water, $70 \mathrm{~mL}$ ) with vigorous stirring. After separation, the aqueous phase was extracted with ethyl acetate (100 $\mathrm{mL} \times 3$ ), and the combined organic phase was dried over anhydrous $\mathrm{Na}_{2} \mathrm{SO}_{4}$, filtered, and concentrated by rotovap to provide crude intermediate which was used for the next step without purification. To the solution of this crude intermediate in dry dichloromethane $(10 \mathrm{~mL})$ was added imidazole $(625 \mathrm{mg}, 9.2$ mmol), then tert-butyldiphenylsilyl chloride $(0.952 \mathrm{~mL}, 3.7 \mathrm{mmol})$ at $0{ }^{\circ} \mathrm{C}$ under $\mathrm{N}_{2}$ atmosphere, after which the reaction was allowed to warm up to rt. TLC showed complete conversion after stirring was continued for 2 hours at rt. The solvent was removed by rotovap, and the residue was redissolved in ethyl acetate $(100 \mathrm{~mL})$. The ethyl acetate solution was washed in sequence with water $(20 \mathrm{~mL} \times 2), \mathrm{HCl}(0.5 \mathrm{~N}, 20 \mathrm{~mL})$, aqueous $\mathrm{NaHCO}_{3}$ (sat., $20 \mathrm{~mL}$ ), brine $\left(20 \mathrm{~mL}\right.$ ), and dried over anhydrous $\mathrm{Na}_{2} \mathrm{SO}_{4}$, filtered, and concentrated by rotovap. The residue was carefully purified by silica gel chromatography to provide product $\mathbf{1 0}(0.32 \mathrm{~g}$, 9\% isolated yield) and product 11 (1.7 g, 47\% isolated yield). The stereochemistry was determined by global deprotection and comparison with reported ${ }^{1} \mathrm{H}$ NMR data ${ }^{4}$. Product $10{ }^{1} \mathrm{H} \mathrm{NMR}(300 \mathrm{MHz}$, Chloroform- $d$ ) $\delta 7.65(\mathrm{~m}, 4 \mathrm{H}), 7.28(\mathrm{~m}, 22 \mathrm{H}), 6.83(\mathrm{~m}, 6 \mathrm{H}), 5.18(\mathrm{~d}, J=4.8 \mathrm{~Hz}, 2 \mathrm{H}), 4.82(\mathrm{~d}, J=10.2 \mathrm{~Hz}$, $1 \mathrm{H}), 4.6(\mathrm{~m}, 5 \mathrm{H}), 4.42(\mathrm{~m}, 2 \mathrm{H}), 4.02(\mathrm{~m}, 1 \mathrm{H}), 3.90(\mathrm{~m}, 1 \mathrm{H}), 3.80(\mathrm{~s}, 6 \mathrm{H}), 3.78(\mathrm{~s}, 3 \mathrm{H}), 3.72(\mathrm{~m}, 1 \mathrm{H}), 3.50$ $(\mathrm{m}, 1 \mathrm{H}), 3.18(\mathrm{~m}, 3 \mathrm{H}), 1.40(\mathrm{~m}, 4 \mathrm{H}), 1.08(\mathrm{~m}, 2 \mathrm{H}), 1.02(\mathrm{~s}, 9 \mathrm{H})$. Product $11{ }^{1} \mathrm{H} \mathrm{NMR}(300 \mathrm{MHz}$, Chloroform- $d$ ) $\delta 7.68(\mathrm{dt}, J=8.1,1.8 \mathrm{~Hz}, 4 \mathrm{H}), 7.40-7.16(\mathrm{~m}, 22 \mathrm{H}), 7.07(\mathrm{~d}, J=8.7 \mathrm{~Hz}, 2 \mathrm{H}), 6.87-6.76$ $(\mathrm{m}, 6 \mathrm{H}), 5.18(\mathrm{~d}, J=4.8 \mathrm{~Hz}, 2 \mathrm{H}), 4.76(\mathrm{~d}, J=10.2 \mathrm{~Hz}, 1 \mathrm{H}), 4.70(\mathrm{~s}, 1 \mathrm{H}), 4.60(\mathrm{dd}, J=12.0,5.4 \mathrm{~Hz}, 2 \mathrm{H})$, $4.51(\mathrm{~s}, 2 \mathrm{H}), 4.48(\mathrm{~m}, 2 \mathrm{H}), 4.37(\mathrm{~d}, J=10.2 \mathrm{~Hz}, 1 \mathrm{H}), 4.06$ (broad, $1 \mathrm{H}), 3.84(\mathrm{~m}, 1 \mathrm{H}), 3.80(\mathrm{~s}, 3 \mathrm{H}), 3.78(\mathrm{~s}$, $6 \mathrm{H}), 3.71-3.56(\mathrm{~m}, 2 \mathrm{H}), 3.21(\mathrm{~m}, 2 \mathrm{H}), 1.46(\mathrm{~m}, 4 \mathrm{H}), 1.20(\mathrm{~m}, 2 \mathrm{H}), 1.06(\mathrm{~m}, 9 \mathrm{H})$. 


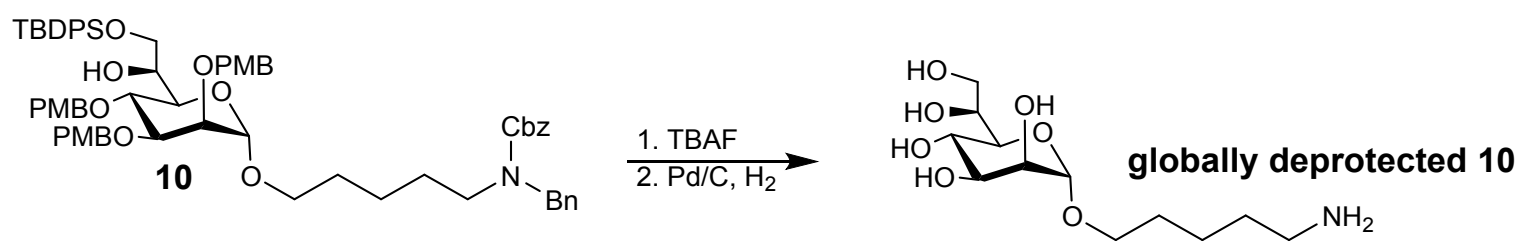

Synthesis of globally deprotected 10 . To the solution of $\mathbf{1 0}(10 \mathrm{mg}, 0.01 \mathrm{mmol})$ in dry THF $(0.4 \mathrm{~mL})$ was added tetrabutylammonium fluoride $(1 \mathrm{M}$ in THF, $0.2 \mathrm{~mL})$. After stirring was continued at $\mathrm{rt}$ for 2 hours, resin (Amberlite $\mathrm{H}$ form) was carefully added until a $\mathrm{pH}$ of 6 was achieved. After filtration and concentration, to the intermediate in $\mathrm{MeOH} / \mathrm{THF} / \mathrm{H}_{2} \mathrm{O} / \mathrm{HOAc}(10 / 5 / 4 / 1,2 \mathrm{~mL})$ was carefully added $\mathrm{Pd} / \mathrm{C}$ $(10 \mathrm{w} \%, 16 \mathrm{mg})$. The reaction atmosphere was switched to $\mathrm{H}_{2}$ using a vacuum- $\mathrm{H}_{2}$ gas balloon technique. After stirring was continued overnight under $\mathrm{H}_{2}$ atmosphere, MS monitoring found complete conversion. Filtration, and concentration by rotovap provided crude product, which was purified by Sephadex G-10 column $\left(\mathrm{H}_{2} \mathrm{O}\right.$ as eluent) to provide globally deprotected $\mathbf{1 0}$ (3 $\mathrm{mg}$, quantitative yield). By comparison of the ${ }^{1} \mathrm{H}-\mathrm{NMR}$ spectra of globally deprotected $10 \&$ globally deprotected 11 , and from the literature ${ }^{4}$, the stereochemistry of position 6 of $\mathbf{1 0}$ and globally deprotected $\mathbf{1 0}$ is determined as desired $S$ configuration. ${ }^{1} \mathrm{H}$ NMR $(300 \mathrm{MHz}$, Methanol-d4) $\delta 4.74(\mathrm{~d}, J=1.7 \mathrm{~Hz}, 1 \mathrm{H}), 3.96(\mathrm{~m}, 1 \mathrm{H}), 3.84(\mathrm{t}, J=9.6 \mathrm{~Hz}, 1 \mathrm{H}), 3.75$ (m, 2H), $3.72-3.53(\mathrm{~m}, 4 \mathrm{H}), 3.40(\mathrm{dt}, J=9.2,5.7 \mathrm{~Hz}, 1 \mathrm{H}), 2.80(\mathrm{t}, J=2 \mathrm{H}), 1.63(\mathrm{~m}, 4 \mathrm{H}), 1.47(\mathrm{~m}, 2 \mathrm{H})$.

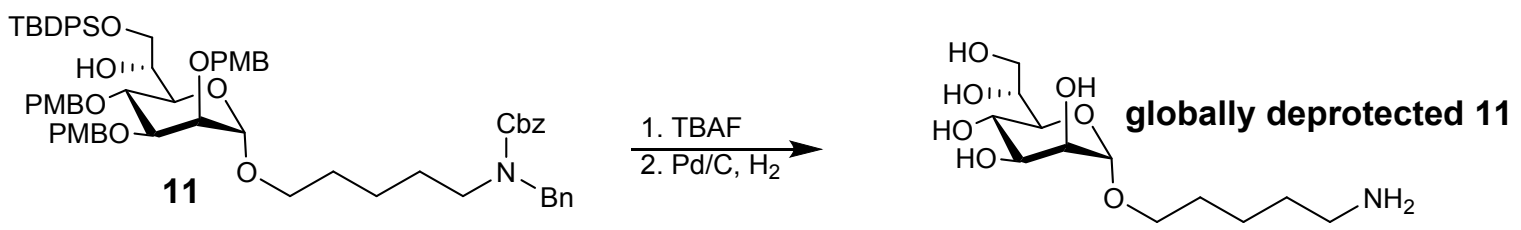

Synthesis of globally deprotected 11. Globally deprotected 11 was made with the same procedure for globally deprotected 10. By comparison of the ${ }^{1} \mathrm{H}-\mathrm{NMR}$ spectra of globally deprotected 10 \& globally deprotected 11, and from the literature ${ }^{4}$, the stereochemistry of position 6 of $\mathbf{1 1}$ and globally deprotected 11 is determined as undesired $R$ configuration. ${ }^{1} \mathrm{H}$ NMR $\left(300 \mathrm{MHz}\right.$, Methanol- $\left.d_{4}\right) \delta 4.80(\mathrm{~d}, J=1.7 \mathrm{~Hz}$, $1 \mathrm{H}), 3.99$ (dd, $J=6.9,3.2 \mathrm{~Hz}, 1 \mathrm{H}), 3.92-3.80(\mathrm{~m}, 4 \mathrm{H}), 3.80-3.71(\mathrm{~m}, 2 \mathrm{H}), 3.66(\mathrm{dd}, J=9.7,4.3 \mathrm{~Hz}$, $1 \mathrm{H}), 3.51(\mathrm{dt}, J=9.8,5.7 \mathrm{~Hz}, 1 \mathrm{H}), 3.01(\mathrm{t}, J=7.5 \mathrm{~Hz}, 2 \mathrm{H}), 1.76(\mathrm{~m}, 4 \mathrm{H}), 1.58(\mathrm{~m}, 2 \mathrm{H})$.
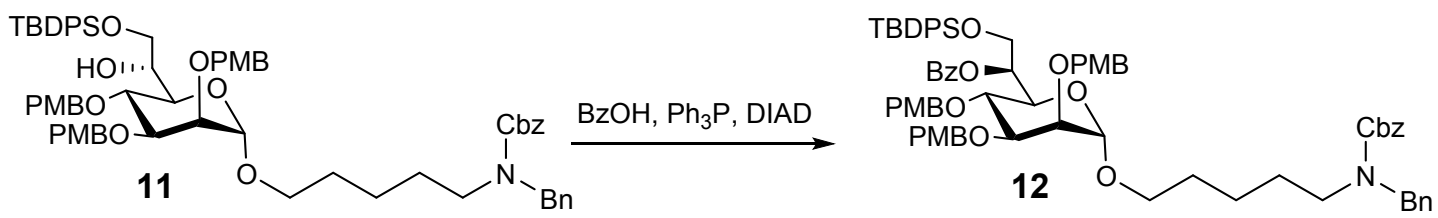

Synthesis of 12. To the solution of $\mathbf{1 1}(500 \mathrm{mg}, 0.45 \mathrm{mmol})$ in dry THF $(15 \mathrm{~mL})$ was added PhCOOH (273 $\mathrm{mg}, 2.2 \mathrm{mmol}), \mathrm{Ph}_{3} \mathrm{P}(577 \mathrm{mg}, 2.2 \mathrm{mmol})$, then diisopropyl azodicarboxylate $(0.44 \mathrm{~mL}, 2.2 \mathrm{mmol})$ at $0{ }^{\circ} \mathrm{C}$ under $\mathrm{N}_{2}$ atmosphere. After stirring was continued overnight, the reaction was allowed to warm up to rt, followed by quenching by the slow addition of hexane $(15 \mathrm{~mL})$ with vigorous stirring. After stirring was continued for 1 hour at $\mathrm{rt}$, the white precipitate was removed by filtration. The filtrate was concentrated by rotovap and residue was purified by silica gel chromatography $(10 \%$, then $25 \%$ ethyl acetate in hexane) to provide product $12\left(341 \mathrm{mg}, 62 \%\right.$ yield). ${ }^{1} \mathrm{H}$ NMR $(300 \mathrm{MHz}$, Chloroform- $d$ ) $\delta 8.03(\mathrm{~m}, 2 \mathrm{H}), 7.64(\mathrm{~m}$, $4 \mathrm{H}), 7.28(\mathrm{~m}, 25 H), 6.83(\mathrm{~m}, 6 \mathrm{H}), 5.76(\mathrm{t}, J=6.8 \mathrm{~Hz}, 1 \mathrm{H}), 5.16(\mathrm{~d}, J=5.0 \mathrm{~Hz}, 2 \mathrm{H}), 4.86(\mathrm{~s}, 1 \mathrm{H}), 4.79-$ $4.65(\mathrm{~m}, 2 \mathrm{H}), 4.61(\mathrm{~m}, 1 \mathrm{H}), 4.57(\mathrm{~s}, 2 \mathrm{H}), 4.45(\mathrm{~m}, 2 \mathrm{H}), 4.38(\mathrm{~d}, J=12.0 \mathrm{~Hz}, 1 \mathrm{H}), 4.07-3.85(\mathrm{~m}, 6 \mathrm{H})$, $3.79(\mathrm{~s}, 3 \mathrm{H}), 3.78(\mathrm{~s}, 6 \mathrm{H}), 3.74(\mathrm{~m}, 1 \mathrm{H}) 3.54(\mathrm{~m}, 1 \mathrm{H}), 3.18(\mathrm{~m}, 2 \mathrm{H}), 3.10(\mathrm{~m}, 1 \mathrm{H}), 1.41(\mathrm{~m}, 4 \mathrm{H}), 1.07(\mathrm{~m}$, 2H), 0.99 (s, 9H). 

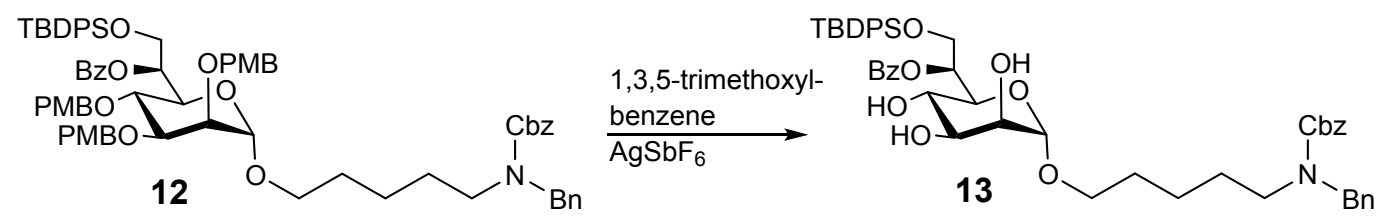

Synthesis of 13. To the solution of $12(1.6 \mathrm{~g}, 1.31 \mathrm{mmol})$ in dry dichloromethane $(10 \mathrm{~mL})$ was added 1,3,5trimethoxylbenzene $(1.54 \mathrm{~g}, 9.15 \mathrm{mmol})$, then $\mathrm{AgSbF}_{6}(445 \mathrm{mg}, 1.31 \mathrm{mmol})$ portion-wise at rt. After stirring was continued for 6 hours at $\mathrm{rt}_{2} \mathrm{Et}_{3} \mathrm{~N}(1 \mathrm{~mL})$ was added to quench the reaction. The residue from the rotovap concentrate was purified by silica gel chromatography ( $50 \%$ ethyl acetate in hexane) to provide product $13\left(850 \mathrm{mg}, 75 \%\right.$ isolated yield). ${ }^{1} \mathrm{H}$ NMR $(300 \mathrm{MHz}$, Chloroform- $d$ ) $\delta 8.09(\mathrm{~m}, 2 \mathrm{H}), 7.62(\mathrm{~m}$, $5 \mathrm{H}), 7.45(\mathrm{t}, J=4.5 \mathrm{~Hz}, 2 \mathrm{H}), 7.32(\mathrm{~m}, 16 \mathrm{H}), 5.50(\mathrm{broad}, 1 \mathrm{H}), 5.18(\mathrm{~d}, J=8.3 \mathrm{~Hz}, 2 \mathrm{H}), 4.74(\mathrm{~d}, J=8.7$ $\mathrm{Hz}, 1 \mathrm{H}), 4.47(\mathrm{~d}, J=7.2 \mathrm{~Hz}, 2 \mathrm{H}), 4.12(\mathrm{~m}, 1 \mathrm{H}), 3.90(\mathrm{~m}, 4 \mathrm{H}), 3.77(\mathrm{t}, J=6.0 \mathrm{~Hz}, 1 \mathrm{H}), 3.56(\mathrm{~m}, 2 \mathrm{H}), 3.19$ (m, 2H), 3.13 (broad, 1H), 2.70 (broad, 1H), 2.30 (broad, 1H), $1.43(\mathrm{~m}, 4 \mathrm{H}), 1.13(\mathrm{~m}, 2 \mathrm{H}), 0.99$ (s, 9H).

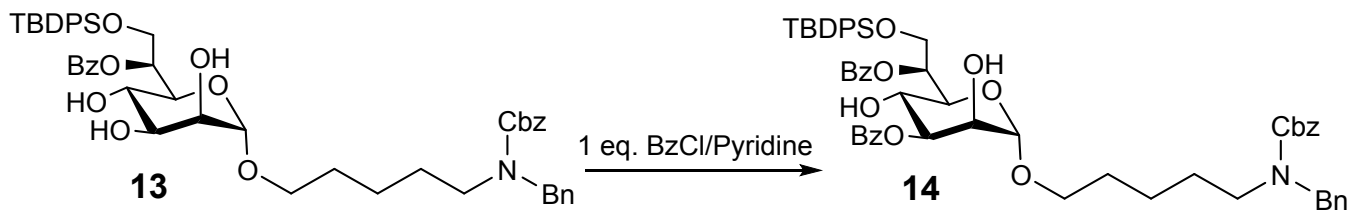

Synthesis of 14. To the solution of $13(70 \mathrm{mg}, 0.08 \mathrm{mmol})$ in dry dichlormethane $(2 \mathrm{~mL})$ was added pyridine $(0.019 \mathrm{~mL}, 0.24 \mathrm{mmol})$, then a dropwise solution of $\mathrm{BzCl}(11 \mathrm{mg}, 0.08 \mathrm{mmol})$ in dry dichloromethane $(0.2 \mathrm{~mL})$ at $0{ }^{\circ} \mathrm{C}$ under $\mathrm{N}_{2}$ atmosphere. After stirring was continued for 1 hour at $0{ }^{\circ} \mathrm{C}$ and $30 \mathrm{~min}$ at rt, TLC showed a major, less polar, new spot (although the conversion was not complete). The reaction mixture was concentrated by rotovap and purified by silica gel chromatography $(15 \%$ first, then $30 \%$ ethyl acetate in hexane) to provide product 14 (35 $\mathrm{mg}, 45 \%$ yield). The regioselectivity was assigned by J coupling constant of $1 \mathrm{D}{ }^{1} \mathrm{H}-\mathrm{NMR}$ and $2 \mathrm{D}$ NMRs. ${ }^{1} \mathrm{H}$ NMR $(300 \mathrm{MHz}$, Chloroform- $d) \delta 8.09(\mathrm{~m}, 4 \mathrm{H})$, $7.63(\mathrm{~m}, 4 \mathrm{H}), 7.34(\mathrm{~m}, 22 \mathrm{H}), 5.63(\mathrm{~m}, 1 \mathrm{H}), 5.43(\mathrm{dd}, J=9.0,3.1 \mathrm{~Hz}, 1 \mathrm{H}), 5.17(\mathrm{~d}, J=14.8 \mathrm{~Hz}, 2 \mathrm{H}), 4.80$ $(\mathrm{d}, J=10.7 \mathrm{~Hz}, 1 \mathrm{H}), 4.49(\mathrm{~s}, 2 \mathrm{H}), 4.11(\mathrm{~m}, 2 \mathrm{H}), 3.97(\mathrm{~m}, 3 \mathrm{H}), 3.53(\mathrm{~m}, 2 \mathrm{H}), 3.18(\mathrm{~m}, 3 \mathrm{H}), 1.45(\mathrm{~m}, 4 \mathrm{H})$, $1.20(\mathrm{~m}, 2 \mathrm{H}), 0.99(\mathrm{~s}, 9 \mathrm{H})$.
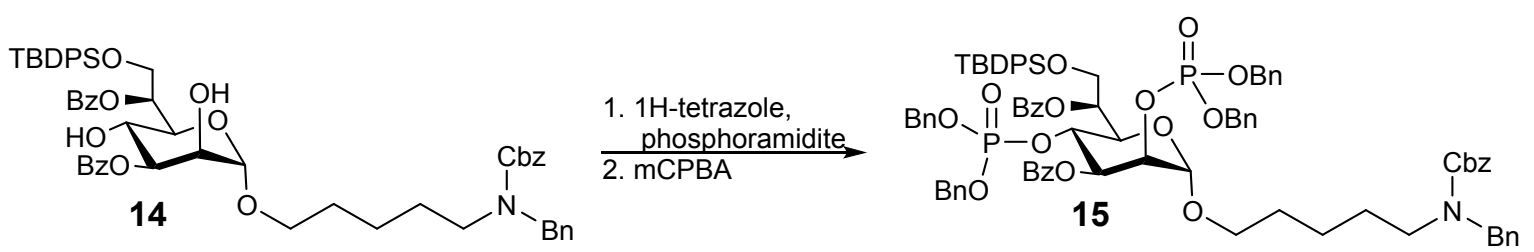

Synthesis of 15. To the solution of $14(26 \mathrm{mg}, 0.035 \mathrm{mmol})$ in dry dichloromethane $(1 \mathrm{~mL})$ was added $1 \mathrm{H}-$ tetrazole $(0.45 \mathrm{M}$ in $\mathrm{MeCN}, 0.8 \mathrm{~mL}, 0.35 \mathrm{mmol})$, then dibenzyl $N, N$-diisopropylphosphoramidite $(90 \mathrm{w} \%$, $0.0891 \mathrm{~mL}, 0.21 \mathrm{mmol}$ ) at $0{ }^{\circ} \mathrm{C}$ under $\mathrm{N}_{2}$ atmosphere. After stirring was continued for $30 \mathrm{~min}$ at $0{ }^{\circ} \mathrm{C}$, then for 1 hour at $\mathrm{rt}$, the reaction mixture was cooled down in an acetonitrile-dry ice bath. To the reaction mixture was added 3-chloroperbenzoic acid ( $70 \mathrm{w} \%$ purity, $100 \mathrm{mg}, 0.4 \mathrm{mmol})$ after which the stirred reaction was allowed to warm up to rt over $30 \mathrm{~min}$, with continued stirring for $30 \mathrm{~min}$ more at $\mathrm{rt}$. The reaction mixture was then diluted with dichloromethane $(10 \mathrm{~mL})$, washed with a mixture of aqueous $\mathrm{NaHCO}_{3}$ (sat., $4 \mathrm{ml}$ ) and $\mathrm{Na}_{2} \mathrm{~S}_{2} \mathrm{O}_{3}(10 \mathrm{w} \%, 4 \mathrm{~mL})$, separated, dried over anhydrous $\mathrm{Na}_{2} \mathrm{SO}_{4}$, filtered, and concentrated by rotovap to provide the residue. The residue was purified by silica gel chromatography $(15 \%$, then $30 \%$ ethyl acetate in hexane) to provide phosphate product 15 (32 $\mathrm{mg}, 62 \%$ yield $) .{ }^{1} \mathrm{H}$ NMR $(300 \mathrm{MHz}$, Chloroform- $d$ ) $\delta 8.05(\mathrm{~m}, 4 \mathrm{H}), 7.65(\mathrm{~m}, 4 \mathrm{H}), 7.44-7.01(\mathrm{~m}, 40 \mathrm{H}), 6.78(\mathrm{~d}, J=6.0 \mathrm{~Hz}, 2 \mathrm{H})$, $5.66(\mathrm{~m}, 2 \mathrm{H}), 5.20(\mathrm{~m}, 3 \mathrm{H}), 5.10-4.83(\mathrm{~m}, 9 \mathrm{H}), 4.66(\mathrm{dd}, J=11.7,6.9 \mathrm{~Hz}, 1 \mathrm{H}), 4.45(\mathrm{~m}, 4 \mathrm{H}), 4.05(\mathrm{~m}$, 2H), $3.72(\mathrm{~m}, 1 \mathrm{H}), 3.22(\mathrm{~m}, 2 \mathrm{H}), 3.14(\mathrm{~m}, 1 \mathrm{H}), 1.46(\mathrm{~m}, 4 \mathrm{H}), 1.21(\mathrm{~m}, 2 \mathrm{H}), 1.04(\mathrm{~m}, 9 \mathrm{H}) .{ }^{31} \mathrm{P}$ NMR $(121$ $\mathrm{MHz}$, Chloroform- $d$ ) $-0.54,-0.81$. 


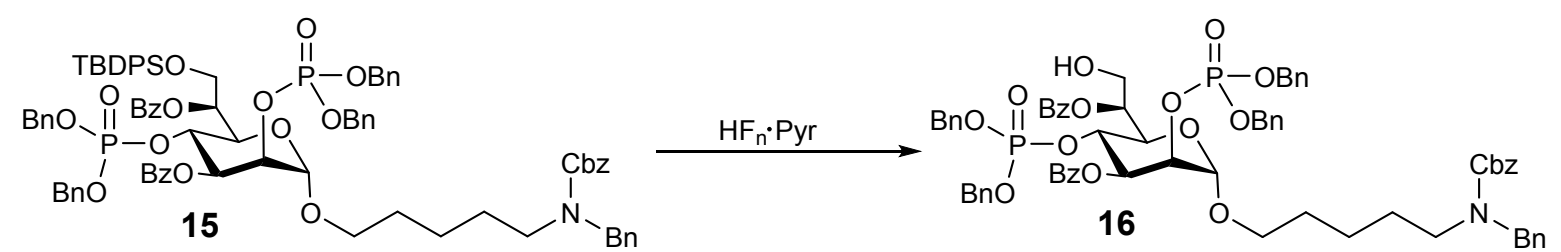

Synthesis of 16. To the solution of $15(30 \mathrm{mg}, 0.02 \mathrm{mmol})$ in dry THF $(1 \mathrm{~mL})$ in a $15 \mathrm{~mL}$ polypropylene tube equipped with a mini stir bar was added $\mathrm{HF}_{\mathrm{n}} \cdot \operatorname{Pyr}(\sim 70 \% \mathrm{HF}, 0.1 \mathrm{~mL})$ at $0{ }^{\circ} \mathrm{C}$. The reaction tube was closed and left in a $4{ }^{\circ} \mathrm{C}$ refrigerator overnight. The reaction was quenched by carefully adding water $(0.05$ $\mathrm{mL}$ ) and $\mathrm{NaHCO}_{3}$ (powder, $200 \mathrm{mg}, 2.4 \mathrm{mmol}$ ) with stirring for 1 hour at rt., after which ethyl acetate (5 $\mathrm{mL})$ and aqueous $\mathrm{NaHCO}_{3}(5 \mathrm{~mL})$ were added with vigorous stirring. After separation, the water phase was extracted with ethyl acetate $(5 \mathrm{~mL}$ x 2$)$. The combined organic phase was dried over anhydrous $\mathrm{Na}_{2} \mathrm{SO}_{4}$, filtered, and concentrated by rotovap. The residue was purified by silica gel chromatography $(30 \%$, then $40 \%$ ethyl acetate in hexane) to provide product $16\left(11 \mathrm{mg}, 43 \%\right.$ yield). ${ }^{1} \mathrm{H}$ NMR (300 MHz, Chloroform- $d$ ) $\delta 8.06(\mathrm{~m}, 4 \mathrm{H}), 7.47-7.05(\mathrm{~m}, 34 \mathrm{H}), 6.78(\mathrm{~d}, J=9.0 \mathrm{~Hz}, 2 \mathrm{H}), 5.60(\mathrm{~d}, J=12.0 \mathrm{~Hz}, 1 \mathrm{H}), 5.40-5.33(\mathrm{~m}$, $1 \mathrm{H}), 5.21(\mathrm{~m}, 3 \mathrm{H}), 5.06-4.87(\mathrm{~m}, 9 \mathrm{H}), 4.63(\mathrm{dd}, J=12.0,9.0 \mathrm{~Hz}, 1 \mathrm{H}), 4.53(\mathrm{~s}, 2 \mathrm{H}), 4.46(\mathrm{~m}, 1 \mathrm{H}), 4.31-$ $4.18(\mathrm{~m}, 1 \mathrm{H}), 4.00-3.92(\mathrm{~m}, 2 \mathrm{H}), 3.74-3.66(\mathrm{~m}, 1 \mathrm{H}), 3.36(\mathrm{~m}, 2 \mathrm{H}), 3.24(\mathrm{~m}, 1 \mathrm{H}), 1.60(\mathrm{~m}, 4 \mathrm{H}), 1.29(\mathrm{~m}$, 2H). ${ }^{31} \mathrm{P}$ NMR (121 MHz, Chloroform- $d$ ) $\delta-0.46,-0.73$.
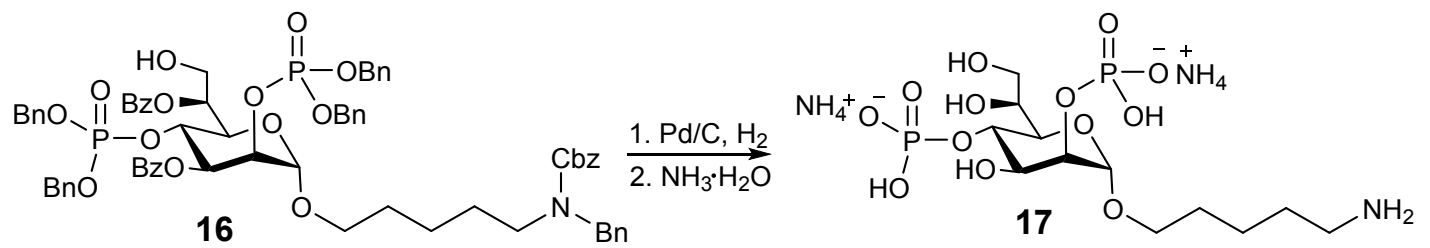

Synthesis of 17. To the solution of $\mathbf{1 6}(17 \mathrm{mg}, 0.014 \mathrm{mmol})$ in $\mathrm{MeOH} / \mathrm{HOAc}(10 / 1,8 \mathrm{~mL})$ was carefully added $\mathrm{Pd} / \mathrm{C},(10 \mathrm{w} \%, 60 \mathrm{mg})$. The reaction atmosphere was switched to $\mathrm{H}_{2}$ using a vacuum- $\mathrm{H}_{2}$ gas balloon technique. After stirring was continued overnight under $\mathrm{H}_{2}$ atmosphere, MS monitoring found complete conversion. Filtration, thoroughly washing the solid, and concentration by rotovap provided $8 \mathrm{mg}$ of crude intermediate. To the glass vial containing crude intermediate $(2 \mathrm{mg}, 0.003 \mathrm{mmol})$ was added aqueous ammonia $(28 \%, 1 \mathrm{~mL})$. The vial was closed with a Teflon-lined cap and kept on a shaker for 20 hours at rt. LCMS showed complete conversion. The reaction mixture was carefully dried by $\mathrm{N}_{2}$ flow in a fume hood to provide the crude product. The crude product was transferred into a $2 \mathrm{~mL}$ polypropylene tube by water $(0.3 \mathrm{~mL} \times 3)$ and lyophilized. The resulting residue was triturated with ethyl acetate $(0.5 \mathrm{~mL} \times 3$, sonicate, centrifuge, and then remove upper ethyl acetate layer by pipette) and dried under high vacuum to provide quantitative and pure product 17. ${ }^{1} \mathrm{H}$ NMR $(300 \mathrm{MHz}$, Deuterium Oxide) $\delta 4.87(\mathrm{~s}, 1 \mathrm{H}), 4.16(\mathrm{~m}$, $2 \mathrm{H}), 3.97(\mathrm{~m}, 1 \mathrm{H}), 3.81(\mathrm{~m}, 1 \mathrm{H}), 3.62-3.49(\mathrm{~m}, 2 \mathrm{H}), 3.38(\mathrm{~m}, 1 \mathrm{H}), 2.84(\mathrm{t}, J=6.0 \mathrm{~Hz}, 2 \mathrm{H}), 1.53(\mathrm{~m}, 4 \mathrm{H})$, $1.32(\mathrm{~m}, 2 \mathrm{H}) .{ }^{31} \mathrm{P}$ NMR $\left(121 \mathrm{MHz}\right.$, Deuterium Oxide) $\delta 4.22,2.81$. LRMS (ESI $\left.{ }^{+}\right) \mathrm{m} / \mathrm{z}$ Cald. for $\mathrm{C}_{12} \mathrm{H}_{28} \mathrm{NO}_{13} \mathrm{P}_{2}[\mathrm{M}+\mathrm{H}]^{+}$456.1, Found 456.0. 


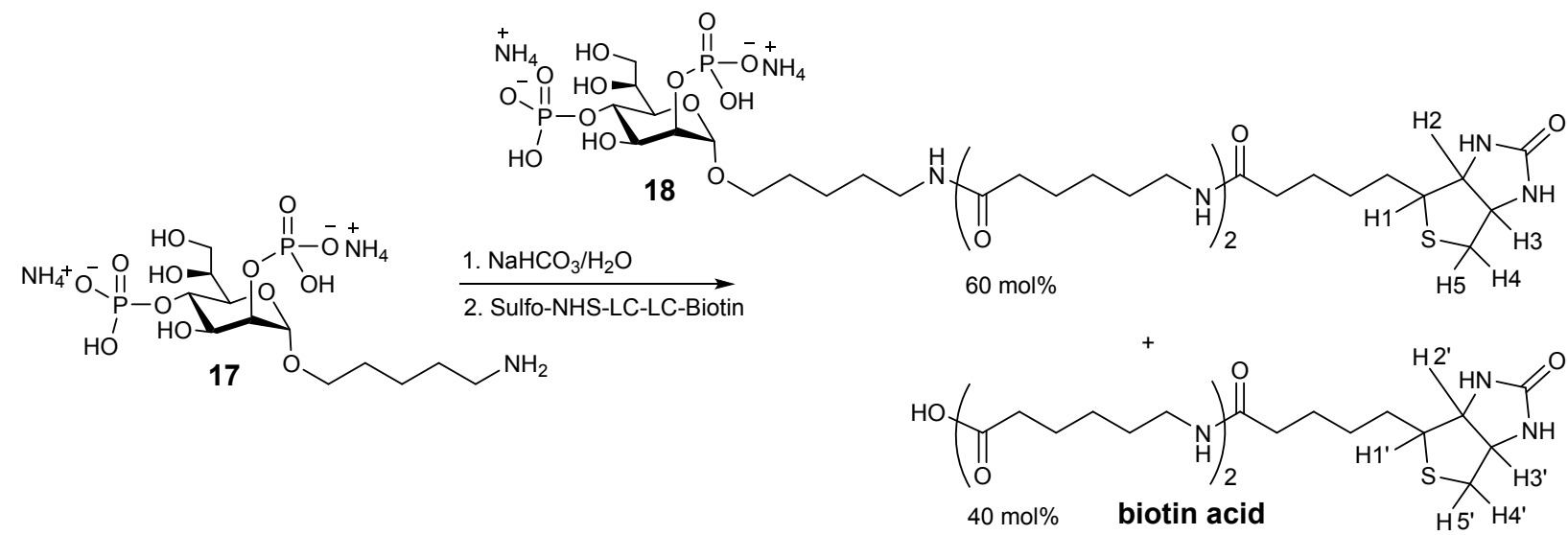

Synthesis of 18. To a solution of $\mathbf{1 7}(1.4 \mathrm{mg}, 0.0031 \mathrm{mmol})$ in distilled water $(1 \mathrm{~mL})$ was added $\mathrm{NaHCO}_{3}$ (powder, $10 \mathrm{mg}, 0.12 \mathrm{mmol}$ ) with gentle shaking. After $30 \mathrm{~min}$ at $\mathrm{rt}$, the mixture was lyophilized overnight (ammonia was removed). To the vial with lyophilized powder was added distilled water $(1 \mathrm{~mL})$, then sulfoNHS-LC-LC-Biotin (ThermoFisher Scientific cat \#: 21338, powder, $4.1 \mathrm{mg}, 0.0062 \mathrm{mmol}$ ). The vial was vortexed for component dissolution, then left at rt overnight. The reaction was loaded on a Sephadex G-10 column (14 x $90 \mathrm{~mm})$, and eluted with milli-Q water. Fractions $(0.3 \mathrm{~mL} /$ fraction) were monitored by MS and those containing product were pooled and lyophilized to provide $2.9 \mathrm{mg}$ ( $60 \mathrm{~mol} \%$ purity of product 18 by ${ }^{1} \mathrm{H}-\mathrm{NMR}$ analysis; the other $40 \mathrm{~mol} \%$ is the "biotin acid" from the hydrolysis of reagent Sulfo-NHSLC-LC-Biotin). This sample was used in octet assays without further purification, but purity is included for yield determination. ${ }^{1} \mathrm{H}$ NMR $(500 \mathrm{MHz}$, Deuterium Oxide) $\delta 4.83(\mathrm{~s}, 1 \mathrm{H}), 4.43(\mathrm{~m}, 1.66 \mathrm{H}, \mathrm{H} 2$ and H2') $4.24(\mathrm{~m}, 1.66 \mathrm{H}, \mathrm{H} 3$ and H3'), $4.15(\mathrm{~m}, 2 \mathrm{H}), 3.93(\mathrm{~m}, 1 \mathrm{H}), 3.79(\mathrm{~m}, 1 \mathrm{H}), 3.56(\mathrm{~m}, 1 \mathrm{H}), 3.49(\mathrm{~m}, 3 \mathrm{H})$, $3.35(\mathrm{~m}, 1 \mathrm{H}), 3.15\left(\mathrm{~m}, 1.66 \mathrm{H}, \mathrm{H} 1\right.$ and $\left.\mathrm{H} 1{ }^{\prime}\right), 2.99\left(\mathrm{~m}, 8.64 \mathrm{H}, \mathrm{CH}_{2} \mathrm{NHCO}\right.$ and $\left.\mathrm{CH}_{2}{ }_{-} \mathrm{NHCO}\right), 2.81$ (dd, $J=$ $13.1,5.1 \mathrm{~Hz}, 1.66 \mathrm{H}, \mathrm{H} 4$ and $\left.\mathrm{H} 4{ }^{\prime}\right), 2.60$ (d, $J=13.1 \mathrm{~Hz}, 1.66 \mathrm{H}, \mathrm{H} 5$ and $\mathrm{H} 5$ '), $2.06\left(\mathrm{~m}, 9.96 \mathrm{H}, \mathrm{CH}_{2} \mathrm{CO}\right.$ and $\left.\mathrm{CH}_{2}{ }^{\prime} \mathrm{CO}\right), 1.57-1.09(\mathrm{~m}, 35.88 \mathrm{H})$. LRMS $\left(\mathrm{ESI}^{+}\right) \mathrm{m} / z$ Cald. for $\mathrm{C}_{34} \mathrm{H}_{64} \mathrm{~N}_{5} \mathrm{O}_{17} \mathrm{P}_{2} \mathrm{~S}^{+}[\mathrm{M}+\mathrm{H}]^{+}$908.4, Found 908.3.

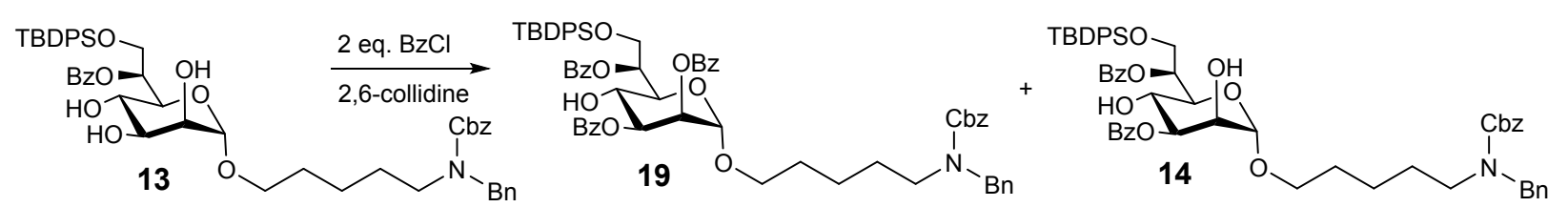

Synthesis of 19 (and alternate route to 14). To the solution of $13(120 \mathrm{mg}, 0.14 \mathrm{mmol})$ in dry dichloromethane $(2 \mathrm{~mL})$ was added 2,6-collidine $(0.093 \mathrm{~mL}, 0.7 \mathrm{mmol})$, then $\mathrm{BzCl}(0.028 \mathrm{~mL}, 0.28 \mathrm{mmol})$ at $\mathrm{rt}$ under $\mathrm{N}_{2}$ atmosphere. Stirring was continued at $\mathrm{rt}$ for 2 days. The reaction mixture was diluted with dichloromethane $(4 \mathrm{~mL})$, washed in sequence with water $(2 \mathrm{~mL}), 1 \mathrm{~N} \mathrm{HCl}(2 \mathrm{~mL})$, and aqueous $\mathrm{NaHCO}_{3}(2$ $\mathrm{mL}$ ), dried over anhydrous $\mathrm{Na}_{2} \mathrm{SO}_{4}$, filtered, and concentrated by rotovap to give the residue purified by silica gel chromatography (15\% first, then 30\% ethyl acetate in hexane) to provide product $19(37 \mathrm{mg}, 25 \%$ yield), as well as product 14 (56 mg, 41\% yield). The regioselectivity was assigned by J coupling constant of 1D ${ }^{1} \mathrm{H}$ NMR. Product $19{ }^{1} \mathrm{H}$ NMR $(400 \mathrm{MHz}$, Chloroform- $d) \delta 8.17(\mathrm{~d}, J=7.7 \mathrm{~Hz}, 2 \mathrm{H}), 7.86(\mathrm{dd}, J=$ 13.3, $7.8 \mathrm{~Hz}, 4 \mathrm{H}), 7.66(\mathrm{~d}, J=6.9 \mathrm{~Hz}, 5 \mathrm{H}), 7.47(\mathrm{t}, J=7.7 \mathrm{~Hz}, 4 \mathrm{H}), 7.33(\mathrm{~m}, 18 \mathrm{H}) 7.13(\mathrm{t}, J=7.7 \mathrm{~Hz}, 2 \mathrm{H})$, $5.75(\mathrm{~m}, 1 \mathrm{H}), 5.67(\mathrm{~d}, J=8.9 \mathrm{~Hz}, 1 \mathrm{H}), 5.55(\mathrm{~s}, 1 \mathrm{H}), 5.18(\mathrm{~d}, J=15.8 \mathrm{~Hz}, 2 \mathrm{H}), 4.94(\mathrm{~m}, 1 \mathrm{H}), 4.51(\mathrm{~s}, 2 \mathrm{H})$, $4.07(\mathrm{~m}, 4 \mathrm{H}), 3.63(\mathrm{~m}, 1 \mathrm{H}), 3.40(\mathrm{~m}, 1 \mathrm{H}), 3.31-3.18(\operatorname{broad}, 3 \mathrm{H}), 1.51(\mathrm{~m}, 4 \mathrm{H}), 1.23(\mathrm{~m}, 2 \mathrm{H}), 1.02(\mathrm{~s}$, 9H). Product $14{ }^{1} \mathrm{H}$ NMR (300 MHz, Chloroform- $d$ ) $\delta 8.09(\mathrm{~m}, 4 \mathrm{H}), 7.63(\mathrm{~m}, 4 \mathrm{H}), 7.34(\mathrm{~m}, 22 \mathrm{H}), 5.63$ $(\mathrm{m}, 1 \mathrm{H}), 5.43(\mathrm{dd}, J=9.0,3.1 \mathrm{~Hz}, 1 \mathrm{H}), 5.17(\mathrm{~d}, J=14.8 \mathrm{~Hz}, 2 \mathrm{H}), 4.80(\mathrm{~d}, J=10.7 \mathrm{~Hz}, 1 \mathrm{H}), 4.49(\mathrm{~s}, 2 \mathrm{H})$, $4.11(\mathrm{~m}, 2 \mathrm{H}), 3.97(\mathrm{~m}, 3 \mathrm{H}), 3.53(\mathrm{~m}, 2 \mathrm{H}), 3.18(\mathrm{~m}, 3 \mathrm{H}), 1.45(\mathrm{~m}, 4 \mathrm{H}), 1.20(\mathrm{~m}, 2 \mathrm{H}), 0.99(\mathrm{~s}, 9 \mathrm{H})$. 

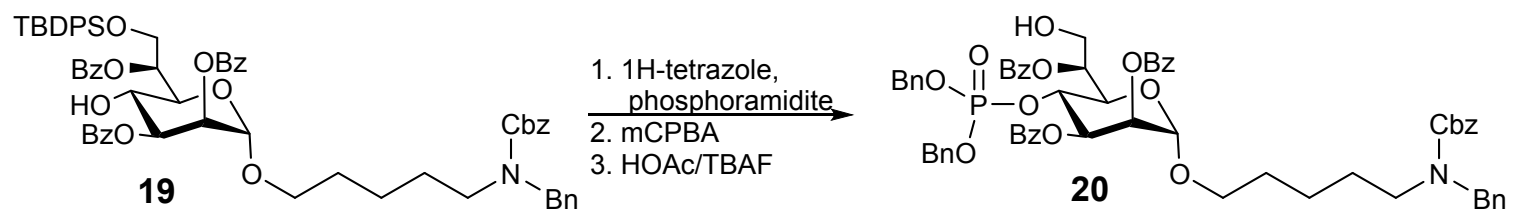

Synthesis of 20. To the solution of $19(48 \mathrm{mg}, 0.048 \mathrm{mmol})$ in dry dichloromethane $(1.3 \mathrm{~mL})$ was added $1 \mathrm{H}$-tetrazole $(0.45 \mathrm{M}$ in MeCN, $0.52 \mathrm{~mL}, 0.24 \mathrm{mmol})$, then dibenzyl $N, N$-diisopropylphosphoramidite $(90$ $\mathrm{w} \%, 0.061 \mathrm{~mL}, 0.14 \mathrm{mmol}$ ) at $0{ }^{\circ} \mathrm{C}$ under $\mathrm{N}_{2}$ atmosphere. After stirring was continued for 0.5 hour at $0{ }^{\circ} \mathrm{C}$ and 1 hour at $\mathrm{rt}$, the reaction mixture was cooled down with an acetonitrile-dry ice bath. To the reaction mixture, 3-chloroperbenzoic acid ( $70 \mathrm{w} \%$ purity, $275 \mathrm{mg}, 0.19 \mathrm{mmol})$ was added and allowed to warm up to $\mathrm{rt}$ in $30 \mathrm{~min}$. After stirring was continued for $30 \mathrm{~min}$ at $\mathrm{rt}$, the reaction mixture was diluted with dichloromethane $(10 \mathrm{~mL})$, washed with a mixture of aqueous $\mathrm{NaHCO}_{3}$ (sat., $\left.4 \mathrm{ml}\right)$ and $\mathrm{Na}_{2} \mathrm{~S}_{2} \mathrm{O}_{3}(10 \mathrm{w} \%, 4$ $\mathrm{mL}$ ), separated, dried over anhydrous $\mathrm{Na}_{2} \mathrm{SO}_{4}$, filtered, and concentrated by rotovap to provide the residue, which was purified by silica gel chromatography $(15 \%$, then $25 \%$ ethyl acetate in hexane) to provide 40 mg of phosphorylated material (contaminated with some dibenzyl $N, N$-diisopropylphosphoramidate from oxidation of phosphoramidite with mCPBA). To the solution of this crude phosphorylated material (40 $\mathrm{mg})$ in dry THF $(2 \mathrm{~mL})$ was added HOAc $(0.311 \mathrm{~mL}, 6 \mathrm{mmol})$, then tetrabutylammonium fluoride (1M in THF, $1.5 \mathrm{~mL}, 1.5 \mathrm{mmol}$ ) at $\mathrm{rt}$ under $\mathrm{N}_{2}$ atmosphere. After stirring was continued for 2 days at $\mathrm{rt}$, the reaction mixture was diluted with ethyl acetate $\left(10 \mathrm{~mL}\right.$ ), washed with aqueous $\mathrm{NaHCO}_{3}$ (sat., $4 \mathrm{~mL}$ ), separated, dried over anhydrous $\mathrm{Na}_{2} \mathrm{SO}_{4}$, filtered, and concentrated by rotovap to give a residue, which was purified with silica gel preparative TLC to provide product $\mathbf{2 0}$ (10 mg, 19\% yield over three steps). ${ }^{1} \mathrm{H}$ NMR (300 MHz, Chloroform- $d$ ) $\delta 8.07(\mathrm{~m}, 4 \mathrm{H}), 7.85(\mathrm{dd}, J=8.3,1.4 \mathrm{~Hz}, 2 \mathrm{H}), 7.63(\mathrm{~m}, 1 \mathrm{H}), 7.52-7.13(\mathrm{~m}, 24 \mathrm{H})$, 7.70 (t, $J=9.0 \mathrm{~Hz}, 2 \mathrm{H}), 6.87(\mathrm{dd}, J=8.2,1.4 \mathrm{~Hz}, 2 \mathrm{H}), 5.86(\mathrm{dd}, J=9.9,3.5 \mathrm{~Hz}, 1 \mathrm{H}), 5.59$ (s, 1H), 5.18 $(\mathrm{m}, J=9.5 \mathrm{~Hz}, 3 \mathrm{H}), 4.99-4.79(\mathrm{~m}, 3 \mathrm{H}), 4.70(\mathrm{~d}, J=9.0 \mathrm{~Hz}, 2 \mathrm{H}), 4.46(\mathrm{~m}, 4 \mathrm{H}), 4.41(\mathrm{~m}, 1 \mathrm{H}), 4.17(\mathrm{~m}$, 1H), $4.02(\mathrm{~m}, 1 \mathrm{H}), 3.54(\mathrm{~m}, 1 \mathrm{H}), 3.32(\mathrm{~m}, 1 \mathrm{H}), 3.16(\mathrm{~m}, 2 \mathrm{H}), 1.43(\mathrm{~m}, 4 \mathrm{H}), 1.11(\mathrm{~m}, 2 \mathrm{H}) .{ }^{31} \mathrm{P}$ NMR $(121$ $\mathrm{MHz}$, Chloroform- $d$ ) $\delta$ 1.06. HRMS $\left(\mathrm{ESI}^{+}\right)$Cald. for $\mathrm{C}_{62} \mathrm{H}_{63} \mathrm{NO}_{15} \mathrm{P}^{+}[\mathrm{M}+\mathrm{H}]^{+}$1092.3935, Found 1092.3979.

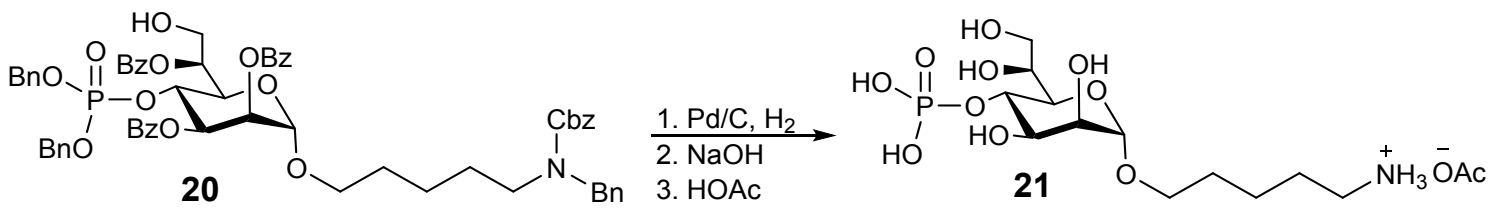

Synthesis of 21. To the solution of $20(7 \mathrm{mg}, 0.007 \mathrm{mmol})$ in $\mathrm{MeOH} / \mathrm{HOAc}(10 / 1,5 \mathrm{~mL})$ was carefully added $\mathrm{Pd} / \mathrm{C}(10 \mathrm{w} \%, 37 \mathrm{mg})$. The reaction atmosphere was switched to $\mathrm{H}_{2}$ using a vacuum- $\mathrm{H}_{2}$ gas balloon technique. After stirring was continued overnight under $\mathrm{H}_{2}$ atmosphere at $\mathrm{rt}$, MS monitoring found complete conversion. Filtration and concentration by rotovap provided crude intermediate, to which in $\mathrm{MeOH}(0.8 \mathrm{~mL})$ was added $\mathrm{NaOH}(0.1 \mathrm{~N}$ in water, $0.05 \mathrm{~mL})$ with stirring at rt. The reaction was monitored by TLC $\left(n-\mathrm{BuOH} / \mathrm{H}_{2} \mathrm{O} / \mathrm{HOAc}=6 / 4 / 4\right)$ after stirring was continued for $20 \mathrm{~min}$ at $\mathrm{rt}$. The operation of adding $\mathrm{NaOH}$ and TLC monitoring was repeated 19 more times until polar intermediates which were more polar than the starting material appeared, then disappeared by TLC $(0.099 \mathrm{mmol}$ of $\mathrm{NaOH}$ was added in total). HOAc $(0.03 \mathrm{~mL})$ was added to quench the reaction. The reaction mixture was passed through a short sephadex G-10 column with distilled water as eluent. Appropriate fractions were pooled and lyophilized to provide quantitative product $\mathbf{2 1}$ (contaminated with a small amount of $\mathrm{BzOH} / \mathrm{BzONa}$ ). Product $\mathbf{2 1}$ was fully characterized by NMR $\left({ }^{1} \mathrm{H},{ }^{1} \mathrm{H}\{31 \mathrm{P}\}\right.$, HSQC, H-H COSY, $\left.{ }^{31} \mathrm{P}\right)$ and MS. ${ }^{1} \mathrm{H}$ NMR $(500 \mathrm{MHz}$, Deuterium Oxide) $\delta 4.72(\mathrm{~s}, 1 \mathrm{H}), 4.18(\mathrm{q}, J=8.9 \mathrm{~Hz}, 1 \mathrm{H}), 3.95(\mathrm{t}, J=6.7 \mathrm{~Hz}, 1 \mathrm{H}), 3.81(\mathrm{~m},, 2 \mathrm{H}), 3.60$ $(\mathrm{m}, 1 \mathrm{H}), 3.54(\mathrm{~m}, 3 \mathrm{H}), 3.38(\mathrm{~m}, 1 \mathrm{H}), 2.85(\mathrm{t}, J=7.8 \mathrm{~Hz}, 2 \mathrm{H}), 1.52(\mathrm{~m}, 4 \mathrm{H}), 1.30(\mathrm{~m}, 2 \mathrm{H}) .{ }^{31} \mathrm{P}$ NMR $(121$ $\mathrm{MHz}$, Deuterium Oxide) $\delta$ 2.45. LRMS (ESI ${ }^{+}$) Cald. for $\mathrm{C}_{12} \mathrm{H}_{27} \mathrm{NO}_{10} \mathrm{P}^{+}[\mathrm{M}+\mathrm{H}]^{+}$376.1, Found 376.0; Cald. for $\mathrm{C}_{12} \mathrm{H}_{26} \mathrm{NNaO}_{10} \mathrm{P}^{+}[\mathrm{M}+\mathrm{Na}]^{+}$398.1, Found 398.0. 


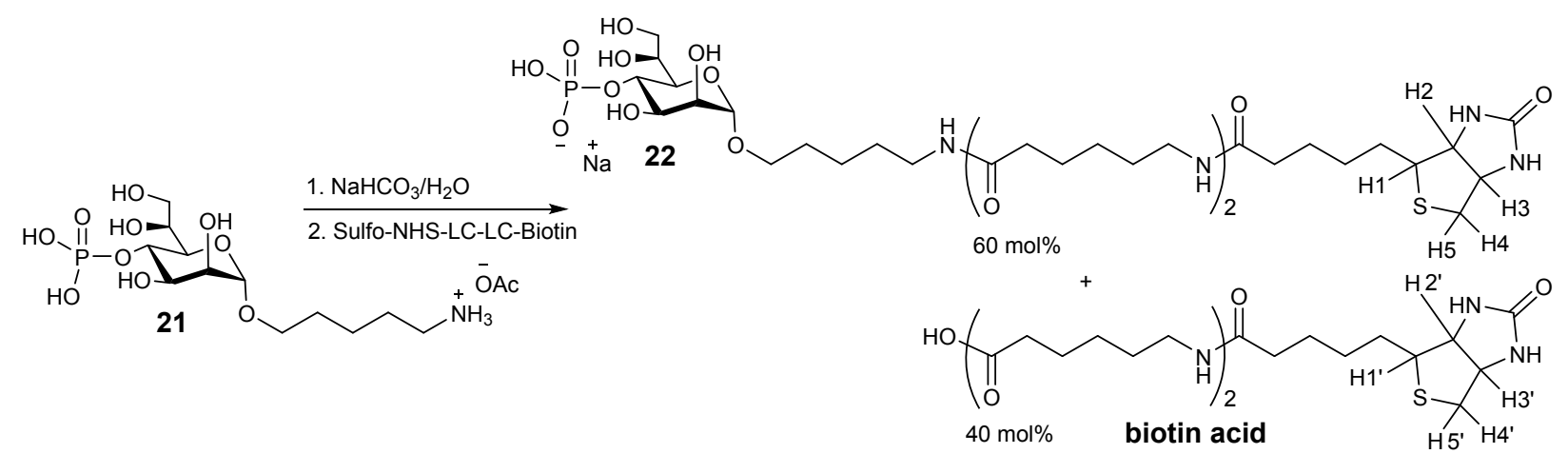

Synthesis of 22. To the solution of $21(0.94 \mathrm{mg}, 0.0021 \mathrm{mmol})$ in distilled water $(0.7 \mathrm{~mL})$ was added $\mathrm{NaHCO}_{3}$ (powder, $5 \mathrm{mg}, 0.0595 \mathrm{mmol}$ ), then Sulfo-NHS-LC-LC-Biotin (ThermoFisher Scientific cat \#: 21338 , powder, $3 \mathrm{mg}, 0.0046 \mathrm{mmol})$ by water rinse $(0.1 \mathrm{~mL} \times 2)$. LC-MS showed complete conversion and product in high ion intensity after the reaction mixture was spun and left at $\mathrm{rt}$ for 4 hours. The reaction mixture was loaded on a Sephadex G-10 column $(14 \times 90 \mathrm{~mm})$ and eluted with distilled water. Fractions $(0.3 \mathrm{~mL} /$ fraction) were monitored by MS and those containing product were pooled and lyophilized to provide $0.4 \mathrm{mg}$ ( $60 \mathrm{~mol} \%$ purity of product 22 by ${ }^{1} \mathrm{H}-\mathrm{NMR}$ analysis; the other $40 \mathrm{~mol} \%$ is the "biotin acid" from the hydrolysis of reagent Sulfo-NHS-LC-LC-Biotin). This sample was used in octet assays without further purification, but purity is included for yield determination. ${ }^{1} \mathrm{H}$ NMR (500 MHz, Deuterium Oxide) $\delta 4.66\left(\mathrm{~s}, 1 \mathrm{H}\right.$ anomeric, overlap with residual $\left.\mathrm{H}_{2} \mathrm{O}\right), 4.43(\mathrm{~m}, 1.66 \mathrm{H}, \mathrm{H} 2$ and $\mathrm{H} 2$ ') $4.24(\mathrm{~m}, 1.66 \mathrm{H}, \mathrm{H} 3$ and H3'), $4.06(\mathrm{~m}, 1 \mathrm{H}), 3.97$ (t, $J=6.4 \mathrm{~Hz}, 1 \mathrm{H}), 3.74(\mathrm{~m}, 2 \mathrm{H}), 3.56(\mathrm{~m}, 1 \mathrm{H}), 3.48(\mathrm{~m}, 3 \mathrm{H}), 3.32(\mathrm{~m}, 1 \mathrm{H}), 3.15$ (m, 1.66H, $\mathrm{H1}$ and $\left.\mathrm{H1}{ }^{\prime}\right), 2.99\left(\mathrm{~m}, 8.64 \mathrm{H}, \underline{\mathrm{CH}}_{2} \mathrm{NHCO}\right.$ and $\left.\mathrm{CH}_{2}{ }_{-} \mathrm{NHCO}\right), 2.81(\mathrm{dd}, J=13.1,5.1 \mathrm{~Hz}, 1.66 \mathrm{H}$, $\mathrm{H} 4$ and $\left.\mathrm{H} 4{ }^{\prime}\right), 2.60$ (d, $J=13.1 \mathrm{~Hz}, 1.66 \mathrm{H}, \mathrm{H} 5$ and $\left.\mathrm{H} 5{ }^{\prime}\right), 2.06\left(\mathrm{~m}, 9.96 \mathrm{H}, \mathrm{CH}_{2} \mathrm{CO}\right.$ and $\left.\mathrm{CH}_{2}{ }^{\prime} \mathrm{CO}\right), 1.57-1.09$ (m, 35.88H). LRMS (ESI $\left.{ }^{+}\right) \mathrm{m} / z$ Cald. for $\mathrm{C}_{34} \mathrm{H}_{63} \mathrm{~N}_{5} \mathrm{O}_{14} \mathrm{P}_{2} \mathrm{~S}^{+}[\mathrm{M}+\mathrm{H}]^{+}$828.4, Found 828.4.

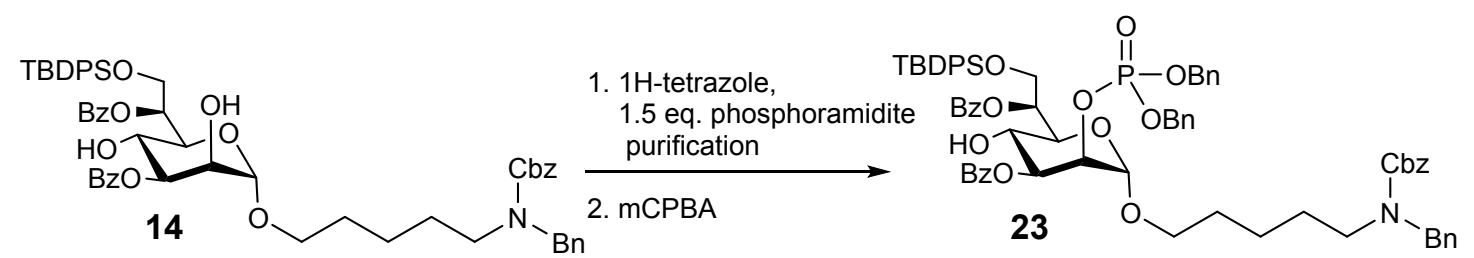

Synthesis of 23. To the solution of $14(50 \mathrm{mg}, 0.05 \mathrm{mmol})$ in dry dichloromethane $(2 \mathrm{~mL})$ was added $1 \mathrm{H}-$ tetrazole $(0.45 \mathrm{M}$ in $\mathrm{MeCN}, 0.55 \mathrm{~mL}, 0.25 \mathrm{mmol})$, followed by dibenzyl $N, N$-diisopropylphosphoramidite $(90 \mathrm{w} \%, 0.01 \mathrm{~mL}, 0.026 \mathrm{mmol})$ at $0{ }^{\circ} \mathrm{C}$ under $\mathrm{N}_{2}$ atmosphere. Stirring was continued for 0.5 hour at rt. Since TLC showed low conversion, the addition of phosphoramidite and TLC monitoring were repeated two more times, and the reaction was stopped at this point to obtain the desired 2-position selectivity. The reaction was concentrated by rotovap and run on an ISCO system ( 2.5 gram cartridge, $15 \%$ ethyl acetate in hexane) to provide impure intermediate. Since the intermediate was impure, it was further purified by PTLC to provide pure 2-phosphite intermediate (22 $\mathrm{mg}, 36 \%$ yield). To the solution of 2-phosphite intermediate $(22 \mathrm{mg}, 0.018 \mathrm{mmol})$ in dry dichloromethane $(1 \mathrm{~mL})$ was added 3-chloroperbenzoic acid (70 $\mathrm{w} \%$ purity, $13 \mathrm{mg}, 0.054 \mathrm{mmol}$ ) at $-40{ }^{\circ} \mathrm{C}$ and the reaction was allowed to warm up to $\mathrm{rt}$ over $30 \mathrm{~min}$. Stirring continued for $30 \mathrm{~min}$ at $\mathrm{rt}$, after which the reaction mixture was diluted with dichloromethane (3 $\mathrm{mL}$ ), washed with a mixture of aqueous $\mathrm{NaHCO}_{3}$ (sat., $2 \mathrm{ml}$ ) and $\mathrm{Na}_{2} \mathrm{~S}_{2} \mathrm{O}_{3}(10 \mathrm{w} \%, 2 \mathrm{~mL}$ ), separated, dried over anhydrous $\mathrm{Na}_{2} \mathrm{SO}_{4}$, filtered, and concentrated by rotovap to provide the residue, which was purified by silica gel chromatography (30\% ethyl acetate in hexane) to provide 2-phosphate product $\mathbf{2 3}$ (17 $\mathrm{mg}, 77 \%$ yield). The regioselectivity was confirmed after global deprotection, which gave 24. Product $23{ }^{1} \mathrm{H}$ NMR (300 MHz, Chloroform- $d$ ) $\delta 8.04$ (dd, $J=15.0,6.0 \mathrm{~Hz}, 4 \mathrm{H}), 7.64(\mathrm{~d}, J=6.0 \mathrm{~Hz}, 4 \mathrm{H}), 7.50(\mathrm{~m}, 2 \mathrm{H}), 7.40-$ $7.10(\mathrm{~m}, 28 \mathrm{H}), 6.99(\mathrm{~d}, J=6.9 \mathrm{~Hz}, 2 \mathrm{H}), 5.64(\mathrm{~m}, 1 \mathrm{H}), 5.48(\mathrm{~d}, J=9.5 \mathrm{~Hz}, 1 \mathrm{H}), 5.20(\mathrm{~s}, 1 \mathrm{H}), 5.15(\mathrm{~s}, 1 \mathrm{H})$, $4.90(\mathrm{~m}, 2 \mathrm{H}), 4.78(\mathrm{~m}, 4 \mathrm{H}), 4.50(\mathrm{~s}, 2 \mathrm{H}), 4.00(\mathrm{~m}, 4 \mathrm{H}), 3.54(\mathrm{~m}, 2 \mathrm{H}), 3.20(\mathrm{~m}, 3 \mathrm{H}), 1.46(\mathrm{~m}, 4 \mathrm{H}), 1.19(\mathrm{~m}$, 2H), 0.99 (s, 9H). ${ }^{31} \mathrm{P}$ NMR (121 MHz, Deuterium Oxide) $\delta-1.04$. 

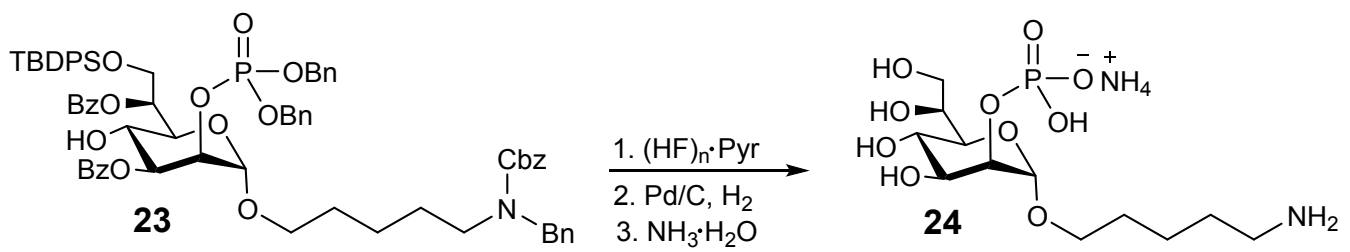

Synthesis of 24. Compound 24 was made from compound 23 using the same procedure as for compound $\mathbf{1 7}$ (made via $\mathbf{1 5} \rightarrow \mathbf{1 6} \rightarrow \mathbf{1 7}$ ). The 2-position selectivity was confirmed by J coupling constant analysis of its ${ }^{1} \mathrm{H},{ }^{1} \mathrm{H}\left\{{ }^{31} \mathrm{P}\right\}$-NMR and their comparison with the 4-phosphate counterpart. Product $24{ }^{1} \mathrm{H}$ NMR (300 $\mathrm{MHz}$, Deuterium Oxide) $\delta 4.82(\mathrm{~s}, 1 \mathrm{H}), 4.12(\mathrm{~d}, J=8.7 \mathrm{~Hz}, 1 \mathrm{H}), 3.85(\mathrm{~m}, 1 \mathrm{H}), 3.73(\mathrm{t}, J=9.0 \mathrm{~Hz}, 1 \mathrm{H})$, $3.50(\mathrm{~m}, 4 \mathrm{H}), 3.36(\mathrm{~m}, 2 \mathrm{H}), 2.81(\mathrm{t}, J=6.0 \mathrm{~Hz}, 2 \mathrm{H}), 1.48(\mathrm{~m}, 4 \mathrm{H}), 1.28(\mathrm{~m}, 2 \mathrm{H}) .{ }^{31} \mathrm{P}$ NMR $(121 \mathrm{MHz}$, Deuterium Oxide) $\delta$ 3.88. LRMS $\left(\mathrm{ESI}^{+}\right) \mathrm{m} / z$ Cald. for $\mathrm{C}_{12} \mathrm{H}_{27} \mathrm{NO}_{10} \mathrm{P}^{+}[\mathrm{M}+\mathrm{H}]^{+}$376.1, Found 375.9.
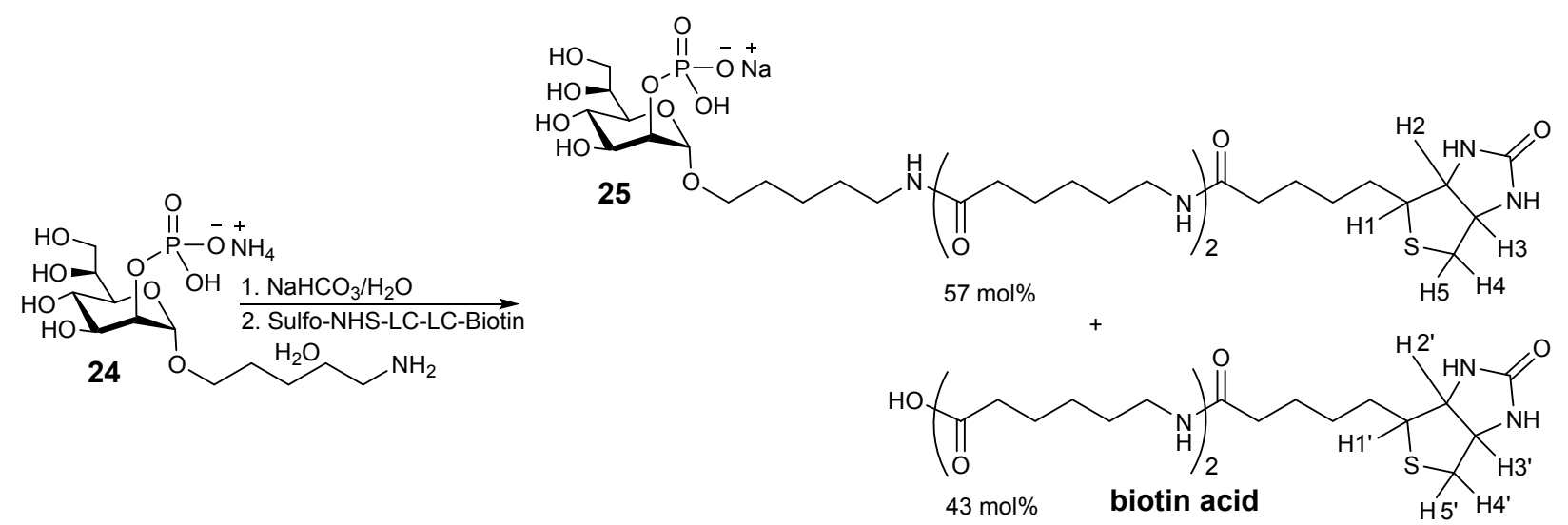

Synthesis of 25. Compound 25 was made from compound 24 using the same procedure as for the 2,4diphosphorylated mannoheptose conjugate 18 (made via $17 \rightarrow \mathbf{1 8}$ ). ${ }^{1} \mathrm{H}-\mathrm{NMR}$ analysis revealed $57 \mathrm{~mol} \%$ purity of 25. Product $25{ }^{1} \mathrm{H}$ NMR $(500 \mathrm{MHz}$, Deuterium Oxide) $\delta 4.82(\mathrm{~s}, 1 \mathrm{H}), 4.42(\mathrm{~m}, 1.75 \mathrm{H}, \mathrm{H} 2$ and H2') $4.24(\mathrm{~m}, 1.75 \mathrm{H}, \mathrm{H} 3$ and H3'), $4.12(\mathrm{~m}, 1 \mathrm{H}), 3.85(\mathrm{~m}, 1 \mathrm{H}), 3.72(\mathrm{t}, J=10.0 \mathrm{~Hz}, 1 \mathrm{H}), 3.60(\mathrm{~d}, J=10$ $\mathrm{Hz}, 1 \mathrm{H}), 3.54(\mathrm{~m}, 1 \mathrm{H}), 3.46(\mathrm{~m}, 3 \mathrm{H}), 3.37(\mathrm{~m}, 3 \mathrm{H}), 3.15(\mathrm{~m}, 1.75 \mathrm{H}, \mathrm{H} 1$ and $\mathrm{H} 1$ ') $), 2.99\left(\mathrm{~m}, 9 \mathrm{H}, \mathrm{CH}_{2} \mathrm{NHCO}\right.$ and CH2'NHCO), 2.81 (dd, $J=13.1,5.1 \mathrm{~Hz}, 1.75 \mathrm{H}, \mathrm{H} 4$ and $\mathrm{H} 4$ '), 2.59 (d, $J=13.1 \mathrm{~Hz}, 1.75 \mathrm{H}, \mathrm{H} 5$ and H5'), $2.05\left(\mathrm{~m}, 10.5 \mathrm{H}, \mathrm{CH}_{2} \mathrm{CO}\right.$ and $\left.\mathrm{CH}_{2}{ }^{\prime} \mathrm{CO}\right), 1.57-1.09(\mathrm{~m}, 37.5 \mathrm{H})$. LRMS (ESI $\left.{ }^{+}\right) \mathrm{m} / z$ Cald. for $\mathrm{C}_{34} \mathrm{H}_{63} \mathrm{~N}_{5} \mathrm{O}_{14} \mathrm{PS}^{+}[\mathrm{M}+\mathrm{H}]^{+}$828.3, Found 828.4. 


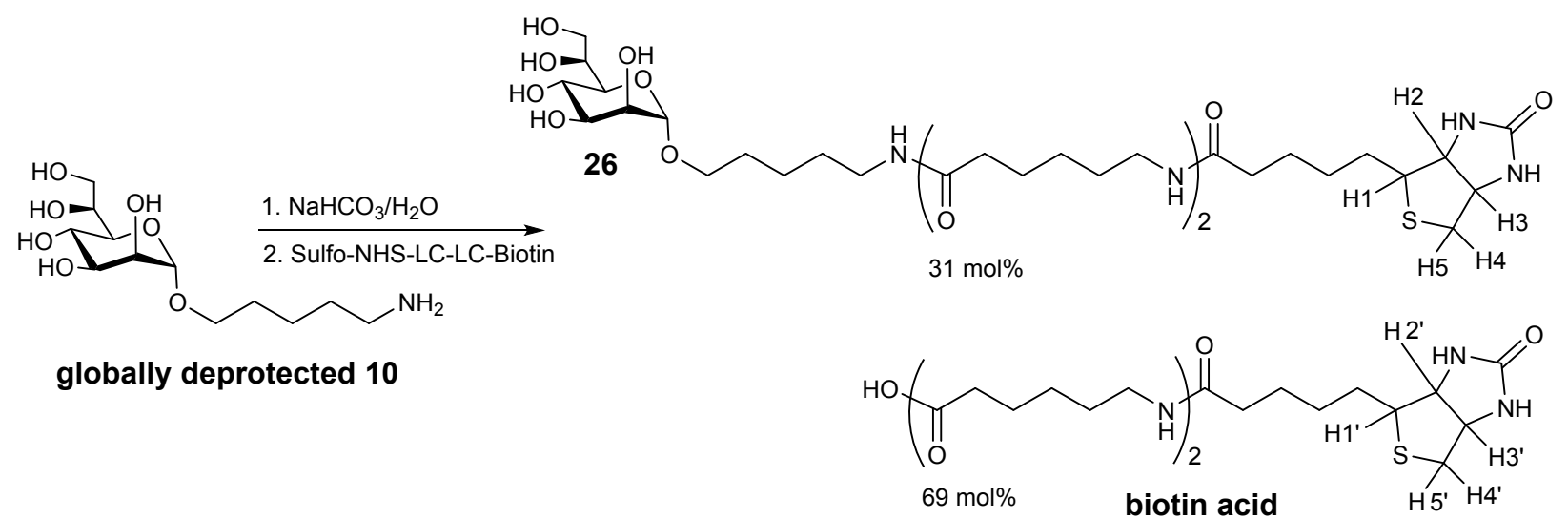

Synthesis of 26. Compound 26 was made from globally deprotected 10 using the same procedure as for the 2,4-diphosphorylated mannoheptose conjugate 18 (made via $\mathbf{1 7} \rightarrow \mathbf{1 8}$ ). ${ }^{1} \mathrm{H}-\mathrm{NMR}$ analysis revealed 31 mol\% purity of 26. Product $26{ }^{1} \mathrm{H}$ NMR $(500 \mathrm{MHz}$, Deuterium Oxide) $\delta 4.66$ (s, $1 \mathrm{H}$ anomeric, overlap with residual $\left.\mathrm{H}_{2} \mathrm{O}\right), 4.43(\mathrm{~m}, 3.2 \mathrm{H}), 4.24(\mathrm{~m}, 3.2 \mathrm{H}), 3.86(\mathrm{~m}, 1 \mathrm{H}), 3.73(\mathrm{~m}, 1 \mathrm{H}), 3.67(\mathrm{t}, J=10.0 \mathrm{~Hz}, 1 \mathrm{H})$, $3.60(\mathrm{~m}, 1 \mathrm{H}), 3.54(\mathrm{~m}, 1 \mathrm{H}), 3.39(\mathrm{~d}, J=10.0 \mathrm{~Hz}, 1 \mathrm{H}), 3.32(\mathrm{~m}, 1 \mathrm{H}), 3.15(\mathrm{~m}, 3.2 \mathrm{H}, \mathrm{H} 1$ and H1'), $2.99(\mathrm{~m}$, $14.8 \mathrm{H}, \mathrm{CH}_{2} \mathrm{NHCO}$ and $\left.\underline{\mathrm{CH}}_{2}{ }^{\prime} \mathrm{NHCO}\right), 2.81$ (dd, $J=13.1,5.1 \mathrm{~Hz}, 3.2 \mathrm{H}, \mathrm{H} 4$ and H4'), 2.59 (d, $J=13.1 \mathrm{~Hz}$, 3.2H, $\mathrm{H} 5$ and $\mathrm{H} 5$ '), $2.04\left(\mathrm{~m}, 19.3 \mathrm{H}, \mathrm{CH}_{2} \mathrm{CO}\right.$ and $\left.\mathrm{CH}_{2}{ }^{\prime} \mathrm{CO}\right), 1.57-1.09$ (m, 64H). LRMS (ESI $\left.{ }^{+}\right) \mathrm{m} / z$ Cald. for $\mathrm{C}_{34} \mathrm{H}_{62} \mathrm{~N}_{5} \mathrm{O}_{11} \mathrm{~S}^{+}[\mathrm{M}+\mathrm{H}]^{+}$748.4, Found 748.3.

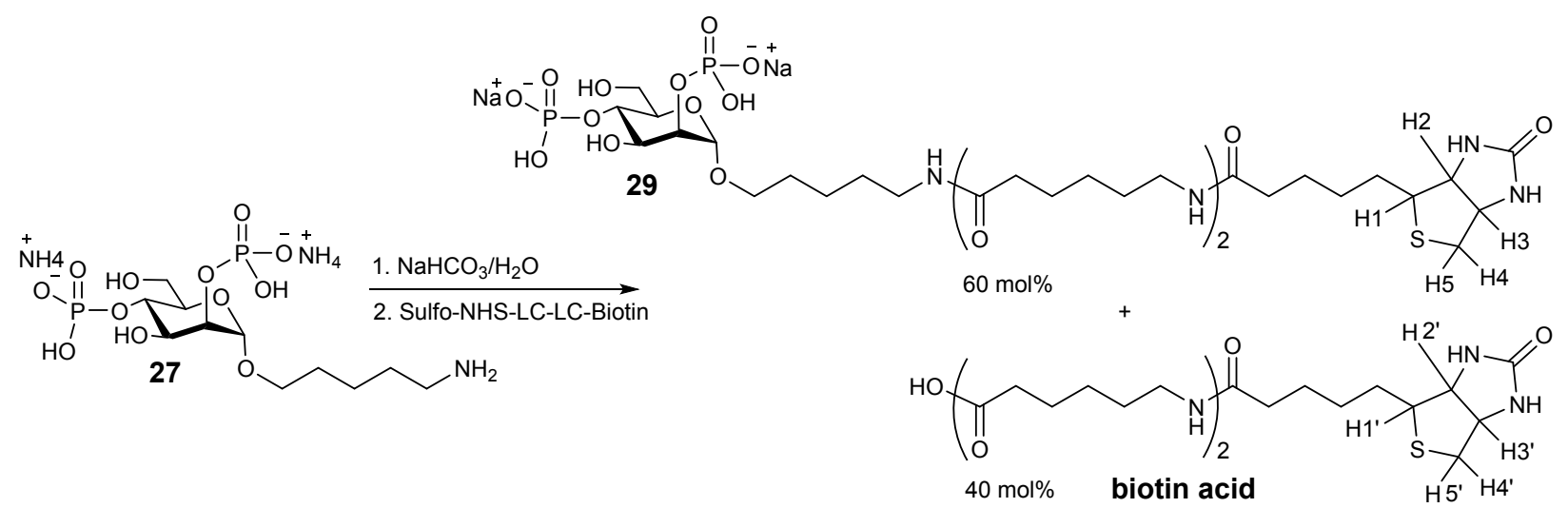

Synthesis of 29. Compound 29 was made from compound 27 using the same procedure as for the 2,4diphosphorylated mannoheptose conjugate 18 (made via $17 \rightarrow \mathbf{1 8}$ ). ${ }^{1} \mathrm{H}$ NMR (500 MHz, Deuterium Oxide) $\delta 4.85(\mathrm{~s}, 1 \mathrm{H}), 4.43(\mathrm{~m}, 1.66 \mathrm{H}, \mathrm{H} 2$ and H2') $4.25(\mathrm{~m}, 1.66 \mathrm{H}, \mathrm{H} 3$ and H3'), $4.16(\mathrm{~d}, J=10.0 \mathrm{~Hz}, 1 \mathrm{H}), 4.01$ $(\mathrm{m}, 1 \mathrm{H}), 3.78(\mathrm{~m}, 1 \mathrm{H}), 3.66(\mathrm{~m}, 2 \mathrm{H}), 3.52(\mathrm{~m}, 2 \mathrm{H}), 3.38(\mathrm{~m}, 1 \mathrm{H}), 3.15(\mathrm{~m}, 1.66 \mathrm{H}, \mathrm{H} 1$ and $\mathrm{H} 1$ '), $3.00(\mathrm{~m}$, 8.64H, $\underline{\mathrm{CH}}_{2} \mathrm{NHCO}$ and $\left.\underline{\mathrm{CH}}_{2}{ }_{2}{ }^{\mathrm{NHCO}}\right), 2.81$ (dd, $J=13.1,5.1 \mathrm{~Hz}, 1.66 \mathrm{H}, \mathrm{H} 4$ and H4'), 2.60 (d, $J=13.1 \mathrm{~Hz}$, $1.66 \mathrm{H}, \mathrm{H} 5$ and $\mathrm{H} 5$ '), $2.06\left(\mathrm{~m}, 9.96 \mathrm{H}, \mathrm{CH}_{2} \mathrm{CO}\right.$ and $\left.\mathrm{CH}_{2}{ }^{\prime} \mathrm{CO}\right), 1.57-1.09(\mathrm{~m}, 35.88 \mathrm{H})$. LRMS $\left(\mathrm{ESI}^{+}\right) \mathrm{m} / z$ Cald. for $\mathrm{C}_{33} \mathrm{H}_{62} \mathrm{~N}_{5} \mathrm{O}_{16} \mathrm{P}_{2} \mathrm{~S}^{+}[\mathrm{M}+\mathrm{H}]^{+}$878.3, Found 878.3. 


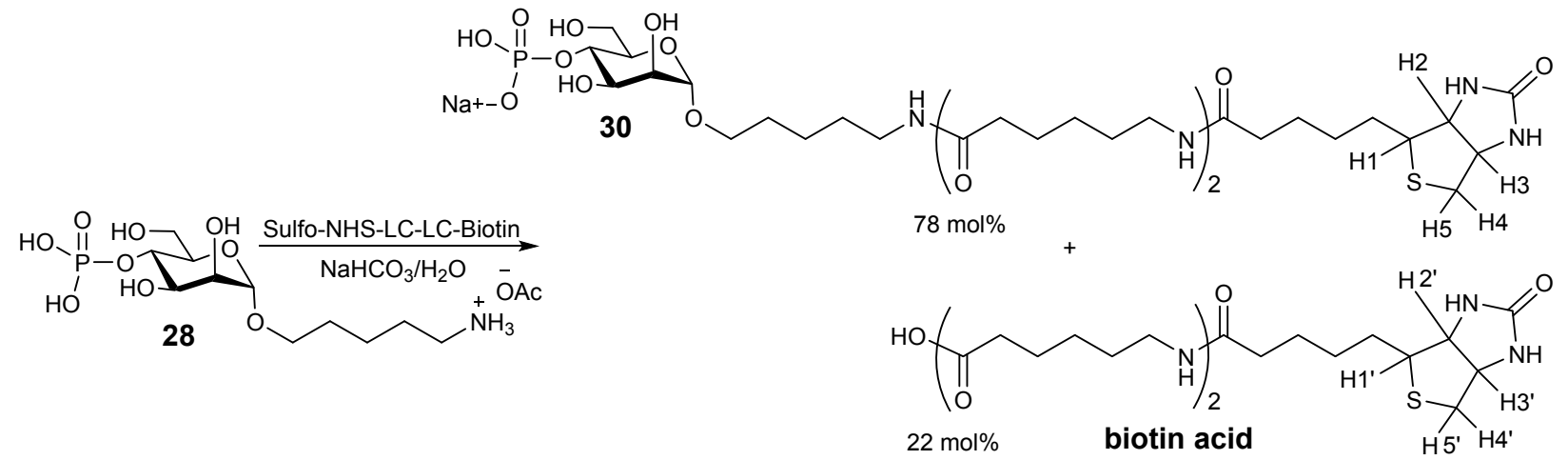

Synthesis of 30. Compound 30 was made from compound 28 using the same procedure as for the 2,4diphosphorylated mannoheptose conjugate 18 (made via $17 \rightarrow \mathbf{1 8}$ ). ${ }^{1} \mathrm{H}$ NMR $(500 \mathrm{MHz}$, Deuterium Oxide) $\delta 4.66(\mathrm{~s}, 1 \mathrm{H}), 4.41(\mathrm{~m}, 1.28 \mathrm{H}, \mathrm{H} 2$ and H2') $4.25(\mathrm{~m}, 1.28 \mathrm{H}, \mathrm{H} 3$ and H3'), $3.94(\mathrm{q}, J=9.2 \mathrm{~Hz}, 1 \mathrm{H}), 3.74$ $(\mathrm{m}, 2 \mathrm{H}), 3.68-3.60(\mathrm{~m}, 2 \mathrm{H}), 3.52(\mathrm{~m}, 2 \mathrm{H}), 3.34(\mathrm{~m}, 1 \mathrm{H}), 3.18\left(\mathrm{~m}, 1.28 \mathrm{H}, \mathrm{H} 1\right.$ and $\left.\mathrm{H} 1^{\prime}\right), 2.98(\mathrm{~m}, 7.12 \mathrm{H}$, $\mathrm{CH}_{2} \mathrm{NHCO}$ and $\left.\mathrm{CH}_{2}{ }_{2} \mathrm{NHCO}\right), 2.81$ (dd, $J=13.1,5.1 \mathrm{~Hz}, 1.28 \mathrm{H}, \mathrm{H} 4$ and $\mathrm{H}^{\prime}$ '), 2.60 (d, $J=13.1 \mathrm{~Hz}, 1.28 \mathrm{H}$, $\mathrm{H} 5$ and $\left.\mathrm{H} 5{ }^{\prime}\right), 2.06\left(\mathrm{~m}, 7.68 \mathrm{H}, \mathrm{CH}_{2} \mathrm{CO}\right.$ and $\left.\mathrm{CH}_{2}{ }^{\prime} \mathrm{CO}\right), 1.57-1.09(\mathrm{~m}, 29.04 \mathrm{H})$. LRMS $\left(\mathrm{ESI}^{+}\right) \mathrm{m} / \mathrm{z}$ Cald. for $\mathrm{C}_{33} \mathrm{H}_{61} \mathrm{~N}_{5} \mathrm{O}_{13} \mathrm{PS}^{+}[\mathrm{M}+\mathrm{H}]^{+}$798.4, Found 798.3.

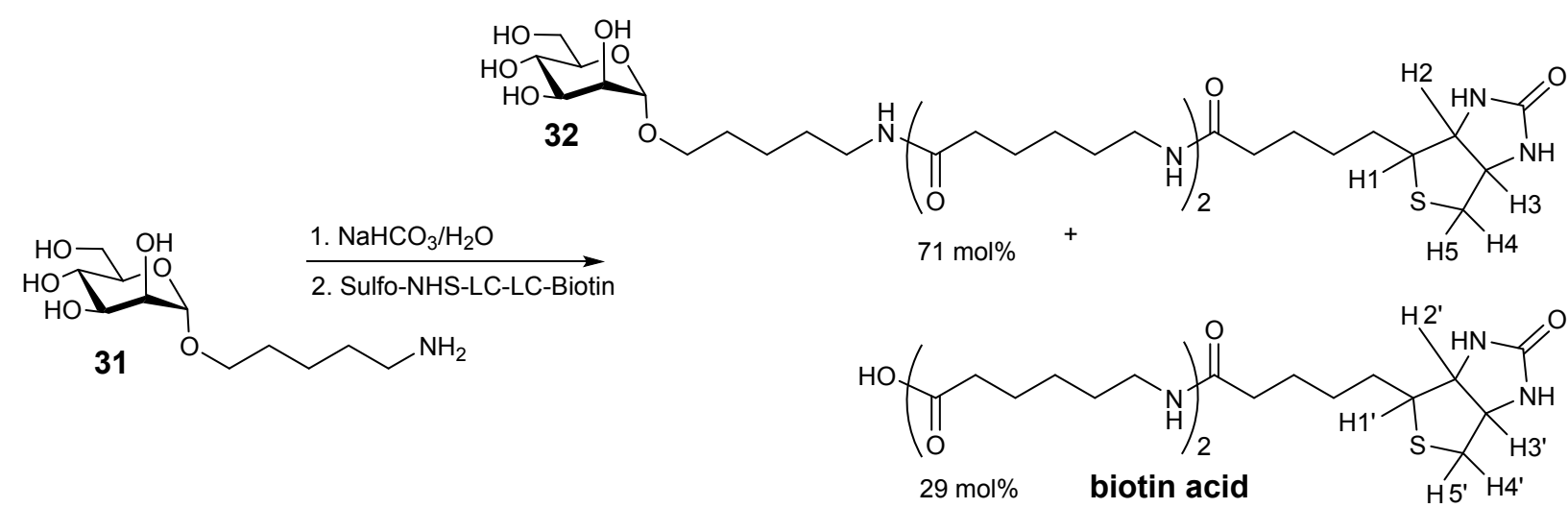

Synthesis of 32. Compound 32 was made from compound 31 using the same procedure as for the 2,4diphosphorylated mannoheptose conjugate 18 (made via $17 \rightarrow \mathbf{1 8}$ ). ${ }^{1} \mathrm{H}$ NMR (500 MHz, Deuterium Oxide) $\delta 4.64$ (s, 1H, overlapped with solvent signal), $4.41(\mathrm{~m}, 1.41 \mathrm{H}, \mathrm{H} 2$ and $\mathrm{H} 2$ ') 4.25 (m, 1.41H, H3 and H3'), $3.72(\mathrm{~m}, 1 \mathrm{H}), 3.68(\mathrm{~d}, J=15.0 \mathrm{~Hz}, 1 \mathrm{H}), 3.59-3.51(\mathrm{~m}, 3 \mathrm{H}), 3.43(\mathrm{~m}, 2 \mathrm{H}), 3.34(\mathrm{~m}, 1 \mathrm{H}), 3.13(\mathrm{~m}, 1.41 \mathrm{H}$, $\mathrm{H1}$ and $\mathrm{H1}$ '), $2.98\left(\mathrm{~m}, 7.64 \mathrm{H}, \underline{\mathrm{CH}}_{2} \mathrm{NHCO}\right.$ and $\left.\underline{\mathrm{CH}}_{2}{ }_{-} \mathrm{NHCO}\right), 2.81(\mathrm{dd}, J=13.1,5.1 \mathrm{~Hz}, 1.41 \mathrm{H}, \mathrm{H} 4$ and $\mathrm{H} 4$ '), $2.60\left(\mathrm{~d}, J=13.1 \mathrm{~Hz}, 1.41 \mathrm{H}, \mathrm{H} 5\right.$ and $\mathrm{H} 5$ '), $2.06-1.96\left(\mathrm{~m}, 8.46 \mathrm{H}, \mathrm{CH}_{2} \mathrm{CO}\right.$ and $\left.\mathrm{CH}_{2}{ }^{\prime} \mathrm{CO}\right), 1.57-1.09$ (m, 31.38H). LRMS (ESI $\left.{ }^{+}\right) \mathrm{m} / z$ Cald. for $\mathrm{C}_{33} \mathrm{H}_{60} \mathrm{~N}_{5} \mathrm{O}_{10} \mathrm{~S}^{+}[\mathrm{M}+\mathrm{H}]^{+}$718.4, Found 718.4.

\section{Supplementary References}

1. Hartmann, M., Krueger, A. et al. Saccharide-Modified Nanodiamond Conjugates for the Efficient Detection and Removal of Pathogenic Bacteria. Chem. Eur. J. 18, 6485-6492 (2012).

2. Jiang, R., Zhang, J. et al. Efficient Synthesis of a High-Mannose-Type Pentasacchride and Hexasaccharide Related to $N$-Glycans. Synthesis 48, 213-222 (2016).

3. Castelli, R.; Overkleeft, H. S.; Van Der Marel, G. A.; Codee, J. D. C. 2,2-Dimethyl-4-(4methoxyphenoxy) butanoate and 2,2-Dimethyl-4-azido butanoate: Two New Pivaloate-ester-like Protecting Groups. Org. Lett. 15, 2270-2273 (2013).

4. Yang, Y., Oishi, S., Martin, C. E., Seeberger, P. H. Diversity-oriented Synthesis of Inner Core Oligosaccharides of the Lipopolysaccharide of Pathogenic Gram-negative Bacteria. J. Am. Chem. Soc. 135, 6262-6271 (2013). 